\title{
Indian Military Modernization and Conventional Deterrence in South Asia
}

\author{
WALTER C. LADWIG III \\ Department of War Studies, King's College London, UK
}

\begin{abstract}
In recent years, headline grabbing increases in the Indian defense budget have raised concerns that India's on-going military modernization threatens to upset the delicate conventional military balance vis-à-vis Pakistan. Such an eventuality is taken as justification for Islamabad's pursuit of tacticalnuclear weapons and other actions that have worrisome implications for strategic stability on the subcontinent. This article examines the prospects for Pakistan's conventional deterrence in the near to medium term, and concludes that it is much better than the pessimists allege. A host of factors, including terrain, the favorable deployment of Pakistani forces, and a lack of strategic surprise in the most likely conflict scenarios, will mitigate whatever advantages India may be gaining through military modernization. Despite a growing technological edge in some areas, Indian policymakers cannot be confident that even a limited resort to military force would achieve a rapid result, which is an essential pre-condition for deterrence failure.
\end{abstract}

KEY WORDS: India, Pakistan, Conventional Deterrence, Military Modernization, Tactical Nuclear Weapons

A series of skirmishes along the Line of Control in Kashmir during the second half of 2014 left more than 50 dead, displaced thousands of civilians, and reignited concerns about the prospects of war between South Asia's two nuclear powers. ${ }^{1}$ Despite the presence of nuclear weapons, conventional deterrence remains the foundation of the 'ugly stability' that persists between India and Pakistan. ${ }^{2}$ However, in recent years, a host of observers have expressed concern that India's on-going military modernization threatens to upset the delicate conventional

\footnotetext{
${ }^{1}$ Frank Daniel, 'Kashmir Shelling, Spat Over Pak Aid Mar Run-up to Kerry Trip,' Reuters, 6 Jan. 2015.

${ }^{2}$ The phrase 'ugly stability' comes from Ashley J. Tellis, Stability in South Asia (Santa Monica, CA: RAND, 1997), 5.
} 
military balance in the region. If true this would have worrisome implications for strategic stability in South Asia since, according to at least one expert estimate, '95 per cent of Pakistan's strategic deterrent relies on a robust conventional military capability...,3

Indian defense spending has doubled in real terms since 1997, growing at an average of 6.3 per cent per year. ${ }^{4}$ The newly elected government of Narendra Modi announced a further 11 per cent hike, raising the 2015-2016 military budget to $\$ 39.8$ billion. Moreover, India is presently the world's largest buyer of conventional weapons, with upwards of $\$ 100$ billion expected to be spent on modernizing its defense forces over the next decade. ${ }^{5}$ Consequently, a number of scholars and analysts have suggested Indian military modernization is threatening Pakistan's conventional deterrence. In turn, this is pressuring them to embrace new nuclear weapons, particularly low-yield warheads and delivery systems for use on the battlefield, so-called tactical nuclear weapons. Although this view appears to be approaching conventional wisdom in many circles, other observers have argued that the Indian military is beset by obsolete platforms and lacks the force integration necessary to exploit transformative military technology. Some have even gone so far as to suggest that it is actually Pakistan which is shifting the conventional balance in its favor. Which of these views is correct?

The analysis presented here suggests that the prospects for Pakistan's conventional deterrence in the near to medium term are much better than the pessimists allege. A host of structural factors mitigate whatever advantages India may be gaining through military modernization: terrain and the deployment of Pakistani forces are not conducive to rapid successes in areas of significant strategic value, in the most likely conflict scenarios India is unlikely to achieve the strategic surprise necessary to make a limited offensive succeed, and there is no evidence that the Indian military possesses a sufficient skill asymmetry over Pakistani forces to overcome these two deficiencies through the use of advanced military technology. Despite a technological edge in some areas, Indian policymakers cannot be confident that even a limited resort to military force would achieve a rapid result, which is an essential pre-condition for deterrence failure.

\footnotetext{
${ }^{3}$ Peter R. Lavoy, 'Islamabad's Nuclear Posture: Its Premises and Implementation,' in Henry D. Sokolski, (ed.), Pakistan's Nuclear Future: Worries Beyond War (Carlisle, PA: US Army War College, Jan. 2008), 131-2.

${ }^{4}$ Information from the Stockholm International Peace Research Institute (SIPRI), $<$ www.sipri.org/databases/milex>.

${ }^{5}$ Rahul Bedi, 'No Guns, No Glory,' Tehelka $9 / 14$ (7 April 2012); Brahma Chellaney, 'India's Missing Hard Power,' Mint, 21 April 2010; Siddharth Srivastava, 'Indian Arms Spree on the Fast Track,' Asia Times, 4 June 2009.
} 
The paper proceeds in four substantive parts. The first section summarizes the debate over Indian military modernization and conventional deterrence. This is followed by a survey of conventional deterrence theory to establish the terms of reference for the study. The third, and longest section of the paper applies the theory of conventional deterrence to the South Asian context, taking into account the impacts of geography, surprise, differential military skill and the conventional force balance to assess India's prospects of achieving a quick victory via the use of ground forces or airpower. A brief conclusion summarizes the research findings.

\section{The Debate Over Indian Military Modernization}

Pakistani leaders view their conventional armed forces as the cornerstone of their strategic deterrent capability and believe, in the words of then President Pervez Musharraf, that 'the conventional balance in South Asia is extremely important to maintain peace in the region. ${ }^{6}$ Unsurprisingly, a number of Pakistani analysts have sounded warnings about the Indian military's growing quantitative and qualitative advantages. ${ }^{7}$ In particular, it has been suggested that the recent flurry of overseas weapons acquisitions from countries like Russia and Israel are specifically designed to enhance the Indian military's reconnaissance, precision-strike, and command and control capabilities, which are cornerstones of the so-called Revolution in Military Affairs (RMA). Pakistani security scholars have suggested that the primary consequence of this growing conventional military disparity will be a reduction in Pakistan's conventional deterrence capability and a subsequent decrease in strategic stability in South Asia. ${ }^{8}$ This concern would appear to be

\footnotetext{
${ }^{6}$ Musharraf quoted in 'No-Win Situation Vital to Peace Says Musharraf,' The News, 12 Aug., 2003; 'Pak's Conventional Deterrence Averted War: Musharraf,' Rediff, 22 June 2002. See also, M. V. Ramana and Zia Mian, 'The Nuclear Confrontation in South Asia,' in SIPRI Yearbook 2003 (Oxford: OUP 2003), 201.

${ }^{7}$ Malik Qasim Mustafa, 'Pakistan's Military Security and Conventional Balance of Power,' Strategic Studies 29/ 1 (Spring 2009), 36.

${ }^{8}$ 'Countries Should Commit to No-First-Use Policy,' Express Tribune, 16 May 2014; Mansoor Ahmed, 'Security Doctrines, Technologies and Escalation Ladders: A Pakistani Perspective' (paper presented at the US-Pakistan Strategic Partnership: A Track II Dialogue, Phuket, Thailand, 18-19 Sept. 2011), 1, 5; Zafar Nawaz Jaspal, 'Perilous Indian Military Buildup,' Weekly Pulse, 2 Nov. 2012; Zulfqar Khan, IndiaPakistan Nuclear Rivalry: Perceptions, Misperceptions, and Mutual Deterrence, (Islamabad: Islamabad Policy Research Institute, Jan. 2005). An alternate argument not explored here is that an asymmetry of military power in India's favor actually enhances stability in South Asia. Raju Thomas, 'The South Asian Security Balance in a Western Dominant World,' in (eds), Balance of Power: Theory and Practice in the 21st
} 
empirically grounded since a number of scholars have found that sudden shifts in the conventional military balance between pairs of states - particularly enduring rivals - increases the prospect of conflict breaking out. ${ }^{9}$ Even more worryingly, informed observers such as the former head of the Pakistan Air Force's Strategic Command, the country's previous ambassadors to the United States and the United Nations, as well as retired senior officers from the Strategic Plans Division (SPD) - the agency responsible for managing Pakistan's nuclear weapons stockpile -have all suggested that Islamabad's inability to keep pace with New Delhi's military build up has increased the pressure to expand Pakistan's nuclear arsenal to include low-yield warheads and short-range missiles such as the $60 \mathrm{~km}$ Nasr. ${ }^{10}$ These comments by non-governmental analysts and retired personnel have been echoed by serving officials. In 2009, the spokesman for Pakistan's Foreign Office warned that 'there are acquisitions of sophisticated weaponry by our neighbor which will disturb the conventional balance between our two countries and hence, lower the nuclear threshold.11 This message was repeated in 2011 by the Director of Arms Control and Disarmament Affairs for the Strategic Plans Division, which administers Pakistan's tactical and strategic nuclear weapons. ${ }^{12}$

Of course, anyone with even a passing familiarity with the politics of South Asia would recognize the incentives that the Pakistani government and government-linked scholars have to exaggerate the impact of

Century, ed. (Stanford UP 2004), 317-18. This logic is rooted in the belief that as a status quo power India is not likely to initiate military operations against its neighbor and that revisionist states like Pakistan only mount a challenge when the capabilities of the two sides converge. A.F.K. Organiski, World Politics (New York: Knopf 1968), 364-6.

${ }^{9}$ Several studies summarized in Daniel S. Geller and J. David Singer, Nations at War: A Scientific Study of International Conflict (Cambridge: CUP 1998), 147.

${ }^{10}$ Air Vice-Marshal Shahzad Chaudhry in Rachel Oswald, 'Pakistan-India Arms Race Destabilizing Strategic Balance, Experts Say,' Global Security News Wire, 20 July 2011; Maleeha Lodhi, 'Pakistan's Nuclear Compulsions,' The News, 6 Nov. 2012; Munir Akram, 'Gambling Against Armageddon,' Dawn, 26 Oct. 2014; Feroz Khan, 'Minimum Deterrence: Pakistan's Dilemma,' RUSI Journal 156/ 5 (Oct. 2011), 48. See also, Agha Umer Farooq, 'Deterrence Stability, Security Doctrines \& Escalation Control in South Asia,' (paper presented at the US-Pakistan Strategic Partnership: A Track II Dialogue, Phuket, Thailand, 18-19 September 2011), 5.

${ }^{11}$ Quoted in Baqir Sajjad Syed, 'Minimum N-Deterrence Will Be Maintained: FO,' Dawn, 21 May 2009.

${ }^{12}$ Air Commodore Khalid Banuri communication to the Congressional Research Service cited in Paul K. Kerr and Mary Beth Nikitin, Pakistan's Nuclear Weapons: Proliferation and Security Issues, (Washington DC: Congressional Research Service, 10 May 2012), 8. 
Indian military acquisitions. However, fears that India's military modernization is reducing Pakistan's conventional deterrent extends beyond the sub-continent. For example, former Assistant Secretary of Defense Peter Lavoy, contends that 'India's military modernization program has led to a growing disparity between the Indian and Pakistani conventional military capabilities,' the result of which 'will be either a regional arms race ... and/or a lowering of the nuclear threshold ... ${ }^{13}$ Long-time South Asia watcher Rodney Jones is far more certain of the impact, having argued for nearly a decade that the growing conventional force imbalance between India and Pakistan 'has destabilizing effects on their nuclear relationship. ${ }^{, 14}$ Specifically, Jones believes that India is outstripping Pakistan in 'revolutionary' military assets such as high-performance aircraft, wide-area communications, reconnaissance, and battlefield awareness. ${ }^{15}$ This view has been echoed by nuclear strategist Paul Bracken who argues that 'India has invested heavily in satellites, advanced radars, signals intelligence, and reconnaissance' assets to cultivate new military capabilities. ${ }^{16}$ As India develops transformative military capabilities, observers fear that 'this conventional asymmetry increases the danger of the nuclear arms race it feeds India's hubris and Pakistan's sense of failure. ${ }^{17}$ Indeed, a number of researchers at Washington DC think tanks, including the Carnegie Endowment, the Congressional Research Service, the Council on Foreign Relations, and the Hudson Institute appear to share the beliefs of the Stimson Center's Michael Krepon that Pakistan's recent embrace of the utility of tactical nuclear weapons and broader Pakistani efforts to enhance the quality and quantity of their nuclear arsenal is a result of 'India's growing conventional capabilities and its more proactive military plans. 18

\footnotetext{
${ }^{13}$ Lavoy, 'Islamabad's Nuclear Posture,' 158.

${ }^{14}$ Rodney W. Jones, 'Conventional Military Imbalance and Strategic Stability in South Asia,' (Univ. of Bradford: South Asian Strategic Stability Unit, March 2005), 5.

${ }^{15}$ Ibid., 4.

${ }^{16}$ Paul Bracken, 'The Problem from Hell: South Asia's Arms Race,' The Diplomat, 29 Nov. 2012.

${ }^{17}$ Tom Hundley, 'Pakistan and India: Race to the End,' Foreign Policy, 5 Sept. 2012, $<$ www.foreignpolicy.com/articles/2012/09/05/race_to_the_end $>$.

${ }^{18}$ Michael Krepon, 'Tac Nukes in South Asia,' Arms Control Wonk, 18April 2012, $<$ http://krepon.armscontrolwonk.com/archive/3419/tac-nukes-in-south-asia >. See also, Toby Dalton and Jaclyn Tandler, 'Understanding the Arms 'Race' In South Asia' (Washington DC: Carnegie Endowment for International Peace, Sept. 2012), 4; Kerr and Nikitin, 'Pakistan's Nuclear Weapons: Proliferation and Security Issues,' 3; Gregory Koblentz, Strategic Stability in the Second Nuclear Age (Washington DC: the Council on Foreign Relations 2014), 27-8; Richard Weitz, 'South Asia's Nuclear Arms Racing,' The Diplomat, 1 Oct. 2011. For a discussion of Pakistani thinking on tactical
} 
Although a number of observers appear to take the 'fact' that India's sizeable and growing conventional military capability is posing a significant threat to Pakistan's conventional deterrent as a given, there are a few dissenting voices. Some Indian analysts have argued that the significant amount of money Pakistan is spending on its own military modernization program - assisted by China and the United States - is actually eroding India's 'slender conventional edge. ${ }^{19}$ In this vein, several retired Indian generals have recently argued that their military lacks conventional superiority over Pakistan as well as the ability to achieve a quick and decisive result against its neighbor. ${ }^{20}$ Despite the dramatic increases in defense spending, Indian analysts contend that the military - in particular the Army - faces numerous capability shortfalls that would hinder military operations against Pakistan. The large number of obsolete tanks, armored vehicles, and artillery pieces, not to mention critical shortages of ammunition and air-defense assets, raise serious questions whether India can undertake large-scale military operations at all, let alone whether ongoing defense modernization really is sharply shifting the conventional balance in its favor. ${ }^{21}$ In this vein, Arun Sahgal and Vinod Anand have damningly written that India's military modernization is primarily designed to address the obsolescence of existing platforms 'rather than part of a well thought out force transformation strategy that takes into account the changing nature of war.' As a result, 'despite

\footnotetext{
nuclear weapons, which does not share the alarmism regarding India's military modernization, see Shashank Joshi, 'Pakistan's Tactical Nuclear: Nightmare: Dé ja' Vu?' The Washington Quarterly 36/ 3 (Summer 2013), 159-72.

${ }^{19}$ Gurmeet Kanwal, India's Military Modernization: Plans and Strategic Underpinnings (Washington DC: National Bureau of Asian Research, Sept 2012), 2.

${ }^{20}$ See the comments of Maj. Gen. G.D. Bakshi, SM, VSM (Retd) and Maj. Gen. Dhruv Katoch (Retd) quoted at 'Pakistan Army: Modernization, Arms Procurement and Capacity Building,' Centre for Land Warfare Studies, New Delhi, India, 21 Feb. 2011. For similar views, see Shekhar Gupta, 'No First-Use Options,' Indian Express, 17 Jan. 2009; Harsh V. Pant, 'India in Afghanistan: A Rising Power or a Hesitant Power?' (paper presented at the CIPSS Speaker Series on International Security and Economy, McGill Univ., 5 April 2012),. 23.

${ }^{21}$ Comptroller and Auditor General, Report No. 24: Union Government (Defence Services) Army and Ordnance Factories, Dec. 2011, 12; G.D. Bakshi, 'Restructuring the Indian Armed Forces,' Journal of Defence Studies. 5/ 2 (April 2011), 26; 'Indian Army Summer Battle Exercise in Rajasthan,' DefenceNow, 28 April 2012; Kanwal, 'India's Military Modernization: Plans and Strategic Underpinnings,' 3; Lt. Gen. B.S. Pawar, 'Indian Army Aviation Corps: Today and Tomorrow,' Defence and Security Alert, Oct. 2012; Kartikeya Sharma and Gautam Datt, 'Parliamentary Standing Committee on Defence Admits Shortage of Ammunition,' India Today, 23 April 2012; Gary Schmitt and Sadanand Dhume, 'Can India’s Military Be Fixed?’ Weekly Standard. 19/ 40 (June 2014).
} 
spending huge sums on force modernization and induction of weapons systems, there is limited or marginal accretion to overall capabilities. $^{22}$

The most visible manifestation of the 'hollowing out' of the Indian Army occurred in the aftermath of the 2008 Mumbai attacks, when then Army chief General Deepak Kapoor reportedly was forced to admit to the country's political leadership that the Army 'was not ready for war' with Pakistan in retaliation for the terrorist attacks. ${ }^{23}$ This view from within India has been bolstered by Stephen Cohen and Sunil Dasgupta, who recently noted the 'puzzling inability of the Indian state to generate sufficient military power to alter its strategic position vis-àvis Pakistan,' and 'the astounding lack of political direction in Indian efforts at military modernization. ${ }^{24}$

The scholars, analysts, and government officials surveyed in this section present two starkly different views of the state of conventional deterrence in South Asia. From one perspective, India's increasing defense spending is rapidly undermining the cornerstone of Pakistan's strategic deterrent and pushing Islamabad towards an increased reliance on nuclear weapons. The alternate point of view presents an Indian military with crippling deficiencies, one that is struggling to maintain capabilities despite sharp increases in defense spending, and one that may even be losing ground to Pakistan in several key areas. Does Pakistan retain the ability to deter India through conventional means alone? Is that ability under threat -justifying a turn to nuclear solutions -or should we have confidence in conventional deterrence in South Asia? It is to these questions that we turn in the subsequent sections.

\section{Conventional Deterrence Theory}

Conventional deterrence is a subset of deterrence that seeks to prevent the outbreak of conflict during a crisis by maintaining the ability to deny an opponent their goals on the battlefield through the use of conventional forces. ${ }^{25}$ This is substantially different from deterrence by

\footnotetext{
${ }^{22}$ Arun Sahgal and Vinod Anand, 'Revolution in Military Affairs and Jointness,' Journal of Defence Studies 1/ 1 (Aug. 2007), 114.

${ }^{23}$ Sandeep Unnithan, 'Not Ready for War,' India Today, 29 Oct. 2011. See also, Siddharth Srivastava, 'Indian Army "Backed Out” Of Pakistan Attack,' Asia Times, 21 Jan. 2009.

${ }^{24}$ Stephen P. Cohen and Sunil Dasgupta, Arming without Aiming: India's Military Modernization (Washington DC: Brookings Institution Press 2010), xii.

${ }^{25}$ John J. Mearsheimer, Conventional Deterrence (Ithaca, NY: Cornell UP 1983), 15. With respect to conventional forces, denying an opponent their objectives is generally considered to be more effective than threats to punish them. The main advantage of conventional weapons over nuclear weapons for deterrence is the credibility of their use in defense of less-than-vital interests. John Stone, 'Conventional Deterrence and the
} 
punishment which seeks to avoid conflict by threatening to retaliate against a target the aggressor holds dear -often, but not always, their civilian population.

The foundation of conventional deterrence theory was laid by John Mearsheimer, who advanced the clear-cut thesis that war is most likely to break out during a crisis when an aggressor believes a quick victory is possible. In contrast, deterrence will hold when a potential attacker judges that the costs of such actions will be high and their chance of success low. ${ }^{26}$ Importantly, he argues that policymakers are likely to be deterred from launching military action -even when it has a high probability of ultimate success -if they believe that the forthcoming conflict will be protracted in nature, and thus victory can only be achieved at a substantial cost. ${ }^{27}$ In other words, if an aggressor believes that attrition is the only strategy available to them, they will desist.

With the probability of success and cost equally important to policymakers -and cost emerging as a function of the speed with which battlefield objectives can be achieved -the question of whether battlefield success can be achieved at a reasonable cost turns on perceptions about the speed with which a decision can be obtained. Mearsheimer's original analysis examined the robustness of conventional deterrence against a range of limited and maximal military strategies irrespective of the presence of nuclear weapons. However, such a discussion of total war without consideration of the two sides' nuclear arsenals lacks plausibility for the present study. Indeed a number of scholars have argued that the presence of nuclear weapons in South Asia means total war is no longer a possibility. ${ }^{28}$ Instead,

Challenge of Credibility,' Contemporary Security Policy. 33/ 1 (April 2012), 119. The primary drawback is that their less than 'absolute' nature means opponents can hold out the prospect of overcoming them with 'technical, tactical, or operational solutions.' Richard Harknett, 'The Logic of Conventional Deterrence and the End of the Cold War,' Security Studies 4/1 (Autumn 1994), 88-9.

${ }^{26}$ Mearsheimer, Conventional Deterrence, . 23-24.

${ }^{27}$ Ibid. For evidence from prospect theory to support these claims, see Jack S. Levy, 'Prospect Theory and International Relations: Theoretical Applications and Analytical Problems,' Political Psychology 13/2 (June 1992), 279-312. For arguments by both academics and elected officials that politicians are risk adverse, see Jay Newton-Small, 'Next Stop, Sacramento?' Time, 23 April 2009; D. Michael Shafer, 'The Unlearned Lessons of Counterinsurgency,' Political Science Quarterly 103/ 1 (Spring 1988), 66.

${ }^{28}$ Vipin Narang, 'Posturing for Peace? Pakistan's Nuclear Postures and South Asian Stability,' International Security 34/. 3 (Winter 2009/10), 64. Among the factors traditionally believed to constitute Pakistan's nuclear 'red lines' is the conquest of a large part of its territory or the destruction of a large portion of its armed forces. Paolo Cotta-Ramusino and Maurizio Martellini, 'Nuclear Safety, Nuclear Stability, and Nuclear Strategy in Pakistan: A Concise Report of a Visit by Landau Network- 
attention will focus solely on the robustness of conventional deterrence in the presence of two limited aims strategies that might be plausibly pursued under the nuclear umbrella.

On land, the limited aims strategy seeks to capture a specific section of enemy territory and then shift to a defensive posture to repel the expected counterattack. Presented with a fait accompli, the defender has the choice between either acquiescing or initiating an unattractive war of attrition to regain the lost territory. The success of the attacker's gambit turns on its ability to achieve strategic surprise and swiftly overcome the limited forces arrayed to defend the objective. If the defender knows an attack is coming, the attacker can still achieve tactical surprise by selecting the specific point of attack, but the range and scope of objectives that can be pursued is constrained. Against a defender who has the ability to quickly react to the initial thrust, the lack of strategic surprise may doom the limited aims strategy.

A second limited aims strategy not originally discussed by Mearsheimer is the use of air or missile strikes against a state to achieve limited political or military objectives. The robustness of deterrence against airstrikes hinges on an assessment of the ability to rapidly achieve the objective at a minimal cost and without escalating the conflict. ${ }^{29}$ The idea that airpower employed against a state's industrial base, military infrastructure, or government apparatus could punish or coerce the target state is hardly a new idea. ${ }^{30}$ However, the contemporary efficacy of this strategy is facilitated by the dissemination of advanced sensor systems, long-range guided munitions and stealth technologies.

Thus, from Mearsheimer's framework, the two judgments policymakers will assess with respect to deterrence against limited aims strategies are the prospects of achieving strategic surprise on the ground and the ability to rapidly strike targets from the air without triggering an escalation of the conflict.

Centro-Volta' (Como, Italy: Landau Network, Jan. 2001), 5. For arguments that even advances in sensors, stealth, precision strike and other 'revolutionary' military technologies will not reverse the effects of nuclear weapons, see Colin S. Gray, 'Nuclear Weapons and the Revolution in Military Affairs,' in T.V. Paul, Richard J. Harknett, and James J. Wirtz (eds) The Absolute Weapon Revisited: Nuclear Arms and the Emerging International Order (Ann Arbor: Univ. of Michigan Press 1998), 124; Bradley A. Thayer, 'The Political Effects of Information Warfare: Why New Military Capabilities Cause Old Political Dangers,' Security Studies 10/ 1 (Autumn 2000), 65.

${ }^{29}$ Manjeet S. Pardesi, 'The Impact of RMA on Conventional Deterrence: A Theoretical Analysis' (Singapore: Institute of Defense and Strategic Studies, Dec. 2005), 23.

${ }^{30}$ Robert Pape, Bombing to Win: Air Power and Coercion in War (Ithaca, NY: Cornell UP, 1996). 


\section{Conventional Deterrence in South Asia}

How exactly might the modernization of Indian conventional forces affect conventional deterrence and the decision to resort to force? To answer that question we must obviously consider the modernization of the forces themselves. Mearsheimer argues that an attacker's belief that he cannot achieve a quick victory is a necessary, but not sufficient, condition for conventional deterrence success. ${ }^{31}$ According to one recent scholarly assessment, advanced military technologies that allow battlefield commanders to accurately pinpoint their opponent's key assets, and precisely strike them from stand-off distances at critical moments could significantly alter that calculus by reducing the risks of casualties and collateral damage. ${ }^{32}$ Indeed, particularly when employed against lesser opponents -as in the 1991 Gulf War, Operation 'Deliberate Force in Bosnia' (1995), Operation 'Allied Force in Kosovo' (1999) and the invasions of Afghanistan and Iraq enthusiasts believe smart weapons and advanced intelligence, surveillance, reconnaissance and targeting (ISRT) networks allow a state significantly greater power projection capabilities while simultaneously reducing both the hazards and the costs of undertaking such operations. ${ }^{33}$ If these 'revolutionary' military technologies appear to make victory a rapid and bloodless affair, political leaders may perceive the resort to military force to be a more attractive option than it had been in the past. This decrease in the perceived cost of military operations and increase in the perceived likelihood of success could, in turn, significantly reduce the effectiveness of conventional deterrence.

Although many analysts have attributed the dramatic results achieved by the United States in the 1991 Gulf War or the 2001 invasion of Afghanistan to the technical capacity of sensor suites, precision-guided munitions, and networked combat units, technology is only part of the story. Rigorous empirical examination of many of these episodes by Stephen Biddle reveals that the results cannot be attributed to a technological asymmetry alone. Rather,

\footnotetext{
${ }^{31}$ Mearsheimer, Conventional Deterrence, 23-4.

${ }^{32}$ Michel Fortmann and Stefanie von Hlatky, 'The Revolution in Military Affairs: Impact of Emerging Technology on Deterrence,' in T.V. Paul, Patrick M. Morgan, and James J. Wirtz (eds.), Complex Deterrence: Strategy in the Global Age (Univ. of Chicago Press 2009), 316.

${ }^{33}$ Eliot A. Cohen, 'Change and Transformation in Military Affairs,' Journal of Strategic Studies 27/3 (Sept. 2004), 404; Michael Sheehan, 'The Changing Character of War,' in John Baylis, Steve Smith, and Patricia Owens (eds), The Globalization of World Politics (New York: OUP 2007), 217.
} 
they are the result of the interaction between technological asymmetry and asymmetric military skill. ${ }^{34}$ When wielded by a skillful military against an unskilled opponent, advanced technology can inflict devastating damage. However, against an opponent approaching parity in military skill, the asymmetry in outcomes vanishes. $^{35}$

As recent experience demonstrates, skilled employment of cover and concealment can hamper the effectiveness of advanced surveillance platforms and precision guided munitions. During the 1999 Operation 'Allied Force', Serbian armed forces were able to disperse and disguise their armed vehicles from detection, while fooling NATO with decoy tanks made out of tetrapaks, wood burning stoves mocked up as artillery pieces and using smoke generators to mislead laser-guided bombs. ${ }^{36}$ Similarly in Afghanistan during Operation 'Enduring Freedom', lesser skilled Afghan Taliban forces were easily detected and targeted at range, but more capable Al-Qa'eda fighters eroded the utility of NATO's advanced sensor systems and long-range precision weapons through 'dispersal, camouflage discipline, use of cover and concealment, and exploitation of dummy fighting positions to draw fire and attention away from their real dispositions. ${ }^{37}$ Despite absolute dominance of the airspace and an asymmetric technology advantage beyond that likely to be seen in any clash between India and Pakistan, in a series of engagements, Western forces and their Afghan allies repeatedly failed to detect the defensive positions of Al-Qa'eda fighters until they were literally fired upon. ${ }^{38}$ Once detected, long-range precision strike proved to be unable to dislodge the defenders -only

\footnotetext{
${ }^{34}$ Stephen Biddle, 'Afghanistan and the Future of Warfare,' Foreign Affairs (March/ April 2003), 31-46; Stephen Biddle, Military Power: Explaining Victory and Defeat in Modern Battle (Princeton UP 2004), 147-9; Stephen Biddle et al., 'Toppling Saddam: Iraq and American Military Transformation' (Carlisle, PA: US Army War College, Strategic Studies Institute April 2004), 22-31.

${ }^{35}$ See the various simulation results reported in Biddle, Military Power, 183-8.

${ }^{36}$ Joseph Fitchett, 'NATO Misjudged Bombing Damage,' International Herald Tribune, 23 June 1999; Paul Richter, 'US Study of War on Yugoslavia Aimed at Boosting Performance,' Los Angeles Times, 10 July 1999. The USAF's interim report on the Kosovo air effort expressly conceded that 'shortfalls remain ... in the USAF's ability to locate and attack moving armor and other ground forces in poor weather. The Air Force needs to continue to develop and improve its ability to do this.' 'The Air War over Serbia: Aerospace Power in Operation Allied Force' (Washington DC: United States Air Force, 1 April 2000), 53.

${ }^{37}$ Stephen Biddle, 'Allies, Airpower, and Modern Warfare: The Afghan Model in Afghanistan and Iraq,' International Security 30/ 3 (Winter 2005/06), 169-70.

${ }^{38}$ Stephen Biddle, 'Afghanistan and the Future of Warfare: Implications for Army and Defense Policy,' (Carlisle, PA: US Army War College, Nov. 2002), 27-8.
} 
close assault by skilled troops carried the day. ${ }^{39}$ Thus, our assessment of the impact that advanced military technology will have on conventional deterrence will depend, in part, on the relative skill balance between the two sides.

A second factor which we need to consider is the actual terrain of the conflict zone. With respect to conventional deterrence, Mearshimer identifies terrain as one of two key factors influencing the likelihood that an attacker's strategy will succeed in overcoming the defenses arrayed against them. ${ }^{40}$ This variable has been relevant to conflict since the dawn of time and classical philosophers of war, ranging from Sun Tzu to Machiavelli to Clausewitz, have all attested to its central importance. ${ }^{41}$ Contemporary strategic thinkers tend to echo this view, suggesting that for the soldier, terrain 'is everything. ${ }^{42}$ Similarly, some large-n studies of conflict outcomes have found that terrain has a greater marginal impact on the likelihood of victory than the capabilities of the forces involved or the strategies they employ. ${ }^{43}$

What are the practical impacts of terrain on contemporary military operations? Mobility for ground forces is significantly higher in flat terrain than in rugged landscape, for example, but casualty rates are also significantly higher due to the absence of opportunities for concealment and cover. ${ }^{44}$ The converse is generally true for more complex terrain. Some analysts suggest advances in real-time information processing and dissemination combined with modern ISR capabilities could provide a military with a level of transparency on the battlefield that would, as the title of one prominent book suggested, 'lift the fog of war. ${ }^{45}$ However, recent American experiences in Iraq and Afghanistan suggest that it will still be some time before even the most modern ISR capabilities can eliminate the fog and friction of war on

\footnotetext{
${ }^{39}$ Biddle, Military Power, 68-9.

${ }^{40}$ Mearsheimer, Conventional Deterrence, 43.

${ }^{41}$ Niccolo Machiavelli, The Prince [1513] (Oxford: OUP 1984), 50-1; Sun Tzu, The Art of War, trans. Lionel Giles (El Paso, TX: Norte Press 2009), 33-6; Carl von Clausewitz, On War, trans. Michael Howard and Peter Paret (Princeton UP 1984), 142. ${ }^{42}$ Joseph Wylie, Military Strategy: A General Theory of Power Control (Annapolis, MD: Naval Institute Press 2014), 42.

${ }^{43}$ Michael C. Desch, Power and Military Effectiveness: The Fallacy of Democratic Triumphalism (Baltimore, MD: Johns Hopkins Press 2010), 40-1. In addition to surprise, Trevor Dupuy finds that the geography of the conflict zone has a significant impact on military effectiveness, with the potential to give 'combat power superiority to an apparently inferior force.' T.N. Dupuy, Attrition: Forecasting Battle Casualties and Equipment Losses in Modern War (Falls Church, VA: Nova Publications 1995), 108.

${ }^{44}$ Dupuy, Attrition, 110.

${ }^{45}$ William A. Owens, Lifting the Fog of War (Baltimore, MD: Johns Hopkins UP 2001), 203.
} 
contemporary battlefields that Clausewitz said distinguishes 'real war from war on paper. ${ }^{46}$

Total battlespace awareness might be a possibility in the open deserts of Iraq; however more complicated terrain poses real limitations: foliage and buildings can impede the ability to detect targets while, in urban areas, the presence of civilians can hinder efforts to discriminate between combatants and non-combatants. In practice, urban sprawl, heavy forests, rough terrain, or inclement weather impedes the precision, speed, and maneuver that advanced ISRT systems appear to promise in theory. As a result, the impact of geography cannot be overlooked when considering the prospects for conventional deterrence in the face of on-going military modernization.

The subsequent sub-sections examine the non-technological elements that shape conventional deterrence for limited aims strategies.

\section{Geography}

The $2,900 \mathrm{~km}$ long Indo-Pak border is characterized by diverse and varied terrain that has differential impacts on military operations. To the north in Kashmir — which has seen fighting in four wars -the landscape is mountainous and heavily forested. When combined with a lack of wide roads, the movement of vehicles and large military formations is significantly hindered. Moreover, much of the highaltitude territory suffers from significant snowfall in winter, high levels of rain, and overall low visibility, the combination of which limit the operability and payload of fixed-wing aircraft and helicopters, as well as disrupting surveillance and surface communications. ${ }^{47}$ Depending on the time of year, it is possible to conduct large-scale military operations across the Line of Control (LoC) separating Indian and Pakistani controlled Kashmir in the areas of Jammu south of the Pir Panjal mountain range and the Kashmir valley. ${ }^{48}$ However, difficult terrain and under-developed transport infrastructure in these areas hinders the ability to concentrate forces, control dispersed units, and marshal

\footnotetext{
${ }^{46}$ Clausewitz, On War, 119; Barry D. Watts, The Maturing Revolution in Military Affairs,' (Washington DC: Center for Strategic and Budgetary Assessments 2011), $11,34$.

${ }^{47}$ Virander Kumar and P.K. Gautam, 'Back to the Basics: Foot and Hoof Mobility in the Mountains,' IDSA Policy Brief (14 Oct. 2011), 3.

${ }^{48}$ Gurmeet Kanwal, 'Military Dimensions of the 2002 India-Pakistan StandoffPlanning and Preparations for Land Operations,' in Zachary S. Davis (ed.), The India-Pakistan Military Standoff: Crisis and Escalation in South Asia (New York: Palgrave MacMillan 2011), 72.
} 
reinforcements and supplies. ${ }^{49}$ Consequently, as Jack Gill notes a 'verity' of combat in Kashmir is that 'a combination of weather, terrain, and logistical hindrances ... makes swift, deep penetrations unlikely, if not impossible, in the face of even minor resistance. ${ }^{50}$ This is hardly ideal for a limited aims offensive that seeks to succeed by quickly overwhelming or bypassing defending forces.

A second section of the border running from Southern Jammu and Kashmir through the Punjab down to northern Rajasthan is marked by a near continuous line of concrete irrigation canals that stretch for $2,000 \mathrm{~km}$. Not only does this network of canals and their tributaries which have a horizontal depth of up to several kilometers in some places -form an obstacle in its own right, they have been turned into defensive fortifications with the addition of large pilings of soil, concrete bunkers, minefields, and fortified gun emplacements. ${ }^{51}$ This barrier system -which runs as close as several kilometers to the international border -significantly hinders the offensive operations of armored vehicles while providing concealed fighting positions for defensive troops who are protected from direct fire and artillery weapons. Securing a bridgehead and mounting a cross-canal assault against a dug-in opponent can be expected to be a time consuming and bloody affair. Beyond the canals, many areas of Pakistani Punjab are densely populated with several sprawling urban centers, which would also limit the pace of military operations and the potential for battlefield awareness.

This section of the border poses several problems for a limited aims offensive. Regardless of whether the attacker achieves strategic surprise, as Mearsheimer notes, the kind of forward defenses found here pose problems for limited incursions on the ground because they allow even thinly populated defenders to offer stiff resistance. ${ }^{52}$ Moreover, the limited aims strategy is based on the belief that in the face of a successful offensive a defender will either acquiesce or attempt a counterattack against the aggressor turned defender that results in an attritional stalemate so costly they eventually abandon it. ${ }^{53}$ In this respect, it should be noted that both Kashmir and the Punjab hold great political significance for both the Indian and Pakistani governments.

\footnotetext{
${ }^{49}$ John H. Gill, 'Military Operations in the Kargil Conflict,' in Peter R. Lavoy (ed.), Asymmetric Warfare in South Asia: The Causes and Consequences of the Kargil Conflict (Cambridge: CUP 2009), 116.

${ }^{50}$ Ibid., 123.

${ }^{51}$ V.K. Sood and Pravin Sawhney, 'Operation Parakram: The War Unfinished (Thousand Oaks, CA: Sage Publications 2003), 150-1.

${ }^{52}$ Mearsheimer, Conventional Deterrence, 54.

${ }^{53}$ Ibid., 56.
} 
Loss of territory in these areas would be unacceptable to the defender, who would be pressured to escalate the conflict either horizontally or vertically instead of abandoning further military action.

The third section of the international border, where the Sindh and Punjab meet, is often described as Pakistan's major point of strategic vulnerability. It is in this region, between Sukkur and Rahim Yar Khan, where the country's primary north-south transportation artery runs extremely close to the international border. Consequently, some analysts have suggested that this leaves Pakistan extremely vulnerable to a central assault that would spilt the country in two. ${ }^{54}$ It would be a significant reversal for the Pakistani government were Karachi and Hyderabad in the south cut off from Lahore and Islamabad in the north by a limited incursion. However, that historical risk has been significantly alleviated by the construction of a largely parallel highway on the western side of the Indus River that can facilitate the movement of goods and military traffic while remaining screened from the international border by a major river. Although this region lacks the extensive fortifications described in the northern Punjab, the presence of irrigation canals and the Indus River will constrain the available axes of advance for a military force moving from the border towards the Sukkur-Rahim Yar Khan region. This in turn will allow Pakistani forces to fight from prepared positions, albeit not as hardened as those found further north.

The southern-most sections of the international border, consisting of the flat, barren deserts of Rajasthan and Gujarat are extremely suitable for mechanized military operations. Indeed, during the 2001-2002 Operation 'Parakram' the Indian Army reportedly concentrated all of its offensive forces in Rajasthan, suggesting that the Thar Desert and the Rann of Kutch is a likely location for either side to undertake a large-scale armored offensive. ${ }^{55}$ Although the open expanse of the Thar Desert lacks the kind of obstacles to a rapid advance found further north, it also lacks the strategic value attached to those regions. Irrigated and developed on the Indian side of the border, on the Pakistani side areas of the harsh desert have been left empty to provide a natural buffer-zone.

The story is similar in the Rann of Kutch, which depending on the monsoons, is alternately a windswept desert or a salt marsh. In either instance, the region has been described by one observer as 'one of the world's least valuable pieces of real estate. ${ }^{56}$ Although relatively easy

\footnotetext{
${ }^{54}$ John Arquilla, 'Nuclear Weapons in South Asia: More May Be Manageable,' Comparative Strategy 16/ 1 (Jan.-March 1997), 16.

${ }^{55}$ Kanwal, 'Military Dimensions of the 2002 India-Pakistan Standoff,' 84.

${ }^{56}$ 'War in a Wind Blown Waste,' Life, 11 June 1965, 33.
} 
to capture in a limited aims offensive, neither of these two areas would offer particularly useful leverage in post-conflict negotiations. Loss of territory in this region would not impose a major cost on Pakistan and if anything would allow it to trade space for time as it readied a counterattack against Indian forces in significantly exposed terrain.

The particular geography of the Indo-Pak border would inhibit an RMA-enabled Indian limited aims offensive in two major ways. First, the difficult terrain in the region north of the Thar Desert would prevent modern sensor and weapons systems from operating at proving ground effectiveness, while the presence of natural and man-made obstacles would hinder a rapid advance. Second, the open spaces further south that would allow an RMA-enabled force to shine lack the kind of strategic objectives that would be worthwhile to target with a limited offensive. Moreover, the vast, open expanse of the desert does not provide significant advantages to an aggressor who subsequently has to defend the territory they seized against a counterattack.

\section{War Initiation and Strategic Surprise}

In his study of conventional deterrence, Mearsheimer repeatedly emphasizes that the success of limited aims strategies that seek to seize and hold enemy territory largely depend on achieving strategic surprise. That is to say that the opponent is completely caught off guard by the attack, in contrast to tactical surprise where he may know an attack is coming, but not its exact location or objective. To evaluate the likelihood that strategic surprise would be achieved in a future conflict between India and Pakistan, it is necessary to consider the scenarios that could lead to war. Many of the assessments of the destabilizing impact of the advanced military technology India is purported to be acquiring implicitly posit a 'bolt from the blue' scenario where an aggressor inflicts catastrophic harm on an unprepared defender's military assets or command structure. However, a sudden surprise strike of this nature is less likely in a future South Asian conflict both because India lacks an incentive to launch an unprovoked attack on Pakistan and because the most likely paths to war will produce a period of warning that will allow Pakistani defenders to prepare.

As the status-quo power in the dispute over the future of Jammu and Kashmir, India has little incentive to launch a surprise attack on its neighbor. ${ }^{57}$ Indeed, the theory of surprise suggests that as the stronger party in the dispute, Indian strategic planners will explicitly eschew

\footnotetext{
${ }^{57}$ Sumit Ganguly, Conflict Unending: India-Pakistan Tensions Since 1947 (New York: Columbia UP 2001), 128.
} 
surprise-based military strategies in favor of more predictable methods of achieving their objectives that do not risk a battle -or an entire war on the ability to achieve surprise. ${ }^{58}$

Even if India wished to launch a surprise attack, it is unlikely to achieve strategic surprise against Pakistan in a future clash because the most likely precipitating events will create a period of warning for Pakistani forces. In the most frequently cited scenario, conflict is triggered by a large-scale act of terrorism within India that is traced back to Pakistan. ${ }^{59}$ Belief that this is the most likely path to war is so widespread that even Pakistani analysts take it as the starting point for their examination of strategic stability in South Asia. ${ }^{60}$ Given that the infiltration of Pakistani forces into Kashmir preceded the 1965 and 1999 wars, a future Pakistani government's decision to do the same -though far less likely than a terrorist attack also cannot be ruled out as a proximate cause of conflict. The key element of either of these most likely scenarios is that the Pakistani government will have prior warning about the imminent commencement of hostilities either because scenes of terror were playing out on international television or because it was infiltrating troops into Indian territory -and is unlikely to be subject to strategic surprise.

Indian response time will also provide a buffer for Pakistan to respond. As is discussed in greater detail below, the majority of the Indian Army's offensive strength is based in the center of the country, far away from the international border. In 2001, five days elapsed between the 13 December attack on the Indian Parliament and the 'general mobilization' of the armed forces for a confrontation with Pakistan. A further three weeks elapsed before the armored columns of India's strike corps were in a position to commence offensive operations against Pakistan. ${ }^{61}$ Similarly, during the 1999 Kargil War, it required

\footnotetext{
${ }^{58}$ James J. Wirtz and Surinder Rana, 'Surprise at the Top of the World: India's Systemic and Intelligence Failure,' in Lavoy, Asymmetric Warfare in South Asia, 212-13.

${ }^{59}$ Peter Bergen and Bruce Hoffman, Assessing the Terrorist Threat (Washington DC: Bipartisan Policy Center, 10 Sept. 2010), 13; Daniel Markey, 'Terrorism and IndoPakistani Escalation,' Contingency Planning Memorandum No. 6 (Washington DC: Council on Foreign Relations, Jan. 2010), 1.

${ }^{60}$ For example, at a recent conference on strategic stability in South Asia held in Islamabad, seven of the nine 'wargames' examining aspects of a future Indo-Pak war posited that conflict began with a Pakistan-linked terrorist attack within India. In the other two scenarios, violence attributed to Hindu nationalists and a deterioration of internal stability in Gujarat were the pretext for an Indian attack on Pakistan. Conference Report, 'Indian Military's Cold Start Doctrine and its Implications for Strategic Stability in South Asia,' (Islamabad, Pakistan: South Asian Strategic Stability Institute, 20-22 July 2010), 30, 31, 34, 40, 44, 46, 52, 57, 62.

${ }^{61}$ Walter C. Ladwig III, 'A Cold Start for Hot Wars? The Indian Army's New Limited War Doctrine,' International Security 32/ 3 (Winter 2007/08), 160-1.
} 
approximately three weeks from the initial detection of the Pakistani incursion -which had proceeded undetected for up to five months -to move 200,000 troops into position to commence military operations in the Kargil sector. ${ }^{62}$

Since 2001, the Indian Army has examined a variety of options for improving its mobilization time, including the deployment of offensive forces closer to the border; the devolution of large armored formations into smaller, more maneuverable units; and the bolstering of defensive forces along the border with additional armored vehicles. Thus far, only the latter measure has been implemented. ${ }^{63}$ Moreover, the Army's efforts to improve its ability to mobilize have not been taken in conjunction with the other armed services and they do not reduce the amount of time the country's political leadership require to deliberate before choosing to employ military force. Consequently, there is likely to be a sufficient delay between whatever event precipitates a future crisis, the Indian government's decision to act, and the actual mobilization of Indian forces, all of which would provide Pakistan with the ability to alert its own force.

With 80per cent of the Pakistan Army's divisions based in provinces adjacent to the international border - the majority of which are forward-deployed in defensive positions -Pakistan's military is postured to repel an Indian attack. Additionally, in recent years it has taken steps to improve its crisis response capability so that it can capitalize on any warning it receives. In early 2012, the Pakistan Army adopted a new force posture mandating 25 per cent of its battalion reserves to immediately mobilize and occupy defensive positions along the border in the event of a large-scale terrorist attack on Indian soil. ${ }^{64}$ Given the previous discussions of the terrain advantages accruing to a defender in Kashmir and the Punjab, even a partial mobilization of Pakistani forces is likely to present a significant obstacle to a limited aims offensive.

\section{Military Skill}

If India were to achieve a substantial modernization edge over Pakistan, can it expect to achieve the dramatic results that characterized the 1991 Gulf War, operations against the Taliban in 2001, or the US-led

\footnotetext{
${ }^{62}$ Gill, 'Military Operations in the Kargil Conflict,' 97; Benjamin S. Lambeth, 'Airpower in India's 1999 Kargil War,' Journal of Strategic Studies 35/ 3 (June 2012), 293.

${ }^{63}$ Christopher Clary and Vipin Narang, 'Doctrine, Capabilities, and (In)Stability in South Asia,' in Michael Krepon and Julia Thompson (eds.), Deterrence Stability and Escalation Control in South Asia (Washington DC: The Stimson Center 2013), 97-8. ${ }^{64}$ Pranab Dhal Samanta, 'New Pak Doctrine: Deploy at Border If Terror Strike in India,' Indian Express 8 Jan. 2012.
} 
invasion of Iraqi in 2003? Does such a sharp skill differential exist between the Indian and Pakistani militaries - particularly their armies that advanced military technology can achieve a maximal result? Although it is never an easy task to assess the prowess of a military in peacetime, we can make some qualified judgments. Some external observers still adhere to the timeworn maxim that Pakistani forces make up for their lesser numbers with a qualitative superiority over their Indian counterparts. ${ }^{65}$ Other analysts suggest that it is India who possesses a distinct qualitative superiority. ${ }^{66}$ Still other scholars of South Asian security issues doubt that there is any meaningful difference between the two nations' military skills at all. ${ }^{67}$ To support these various viewpoints analysts can cite ample evidence from recent conflicts as to the tactical and operational prowess of one side and the shortcomings of the other. ${ }^{68}$

However, for the purposes of this study, the relevant question is not just the existence of a skill gap per se, but a gap so large that it would allow India's modern weapons systems to operate with proving ground effectiveness in a manner that would overcome the effects of geography and lack of surprise as described above. One way to get a rough approximation of the potential skill differential between Indian and Pakistani forces is to look at per capita spending per soldier, which some scholars have used as a crude proxy for the relative training and

\footnotetext{
${ }^{65}$ 'Pakistan Has Quality Army, India Has Quantity, Say Experts,' Agence FrancePresse, 22 May 2002.

${ }^{66}$ John E. Peters et al, War and Escalation in South Asia (Santa Monica, CA: RAND Corporation 2006), 36-7.

${ }^{67}$ Author interview with John H. Gill, Associate Professor, Near East and South Asia Center for Strategic Studies, Washington DC, Nov. 2012.

${ }^{68}$ For example, Grauer and Horowitz judge that in the 1971 war, the Indian Army employed cover, concealment, dispersion, small-unit maneuver, and combined arms operations -which are a hallmark of sophisticated conventional militaries and essential for exploiting the potential of 'revolutionary' military technology -'at a very high level.' Pakistani forces, in contrast, were found to have skillfully employed these tools at the tactical level, but failed to do so operationally. Ryan Grauer and Michael C. Horowitz, 'What Determines Military Victory? Testing the Modern System,' Security Studies 21/1 (2012), 100. More recently, in Kargil in 1999, irrespective of the strategic wisdom of the incursion, Pakistani forces were also found to demonstrate great tactical prowess in preparing their fighting positions, employing artillery, and conducting small-unit operations. Gill, 'Military Operations in the Kargil Conflict,' 120. In contrast, during the ten-month 'twin peaks' crisis in 2001-2002, the Indian Army suffered 798 casualties, mainly due to 'mishaps in minefields, mishandling of ammunition and explosives and traffic accidents,' which some observers suggested illustrated the 'inexperience' of the Army. Keith Flory, 'Military Muscle,' Statesman, 20 May 2002; 'Parakram Killed More Than Kargil,' Times of India, 2 Aug. 2003.
} 
sophistication of a military. ${ }^{69}$ By this measure, India would have a 3.5:1 advantage over its neighbor. ${ }^{70}$ To put this in perspective, in the 1991 Gulf War -which first alerted the world to the awesome potential of the 'revolution in military affairs'-the quality of US forces as measured by spending per combatant was between 16 and 20 times that of their Iraqi opponents. ${ }^{71}$ When the two sides clashed again in 2003, US spending per soldier was as high as 58 times greater than that of Iraq. ${ }^{72}$ The quantitative estimate of a skill gap between Indian and Pakistani forces is five times smaller than the smallest calculated differential between US and Iraqi forces. Thus, even if we credit India with a qualitative superiority in the training of its forces, there is little reason to believe that Indian forces would be able to achieve a similarly rapid and decisive victory over their Pakistani opponents, even if they possessed a substantially more sophisticated military technology base.

The salient points of the discussion in this section are that (1) the terrain in much of the border region is rough, favors the defender, and has a high potential to degrade the transparency promised by advanced sensor and strike systems, (2) the most likely triggers for a future conflict are almost certain to preclude India from being able to achieve strategic surprise against its neighbor, (3) Indian strategic planners cannot have a high degree of confidence that their forces possess sufficient skill advantages over their opponents that they could leverage advanced military technology to overcome the disadvantages posed by the other two factors.

\footnotetext{
${ }^{69}$ See, for example, Paul Huth, Standing Your Ground (Ann Arbor: Univ. of Michigan Press 1996), 258; Allan C. Stam, Win, Lose or Draw (Ann Arbor: Univ. of Michigan Press 1996), 94-5. This measurement has a number of recognized shortcomings in cross-country comparisons since the results can be distorted by the costs of capital intensive services (such as the Air Force and Navy) which 'spend' significantly more per combatant than land elements due to the exorbitant costs of their platforms, as well as the difference in cost structures between professional and conscript-based militaries. However, these problems are reduced for a comparison of extremely similar militaries, like India and Pakistan, and the measure is only employed here to generate rough order of magnitude estimates.

${ }^{70}$ Author's calculations based on defense spending figures collected by SIPRI and the force sizes reported in the International Institute for Strategic Studies, The Military Balance 2012 (London: Routledge for IISS 2012).

${ }^{71}$ Author's calculations based on figures drawn from SIPRI, the IISS Military Balance 1990, 1991, and Anthony H. Cordesman, Iraqi Military Forces Ten Years After the Gulf War (Washington DC: Center for Strategic and International Studies Aug. 2000). The range of estimates arises from discrepancies among these sources as to Iraqi defense spending in 1990 -the year before the conflict.

${ }^{72}$ Author calculations based on figures drawn from SIPRI, the IISS Military Balance 2003, and the 2002 CIA World Fact Book.
} 


\section{The South Asian Military Balance}

Having examined the structural and environmental factors that will affect military operations, and hence conventional deterrence, the discussion in this section looks at the correlation of forces between India and Pakistan. Mere accounting of the numbers and types of weapons-systems in a state's arsenal -frequently derided as 'bean counting'-is by itself insufficient for measuring a state's military power or potential. However, when employed alongside measures of a military's skill and sensitive to the technical sophistication of the platforms in question, force structure is a necessary component of any assessment. ${ }^{73}$ This is particularly true in this instance since a number of observers have suggested that it is India's growing lead in both numbers and sophistication of weapons systems that is driving Pakistan's interest in tactical nuclear weapons. ${ }^{74}$

Attention here will focus on the air and ground balance. This is not to discount the importance of seapower; however, irrespective of the great disparity in naval capability between India and Pakistan, it is unlikely to play a meaningful role in support of a limited aims strategy. ${ }^{75}$ The two major ways that seapower can affect events on land is through naval bombardment or a blockade of enemy ports. ${ }^{76}$ The former approach has been derided as 'pinprick warfare' that has 'little effect on the target state' rather than a serious strategy. ${ }^{77}$ Presently, the Indian Navy has yet to acquire a robust ability to undertake strikes against targets ashore with either naval aircraft or cruise missiles. ${ }^{78}$ India currently possesses a modern 45,000-ton Russian-built aircraft carrier and a second smaller British-built carrier that is on the verge of decommissioning. However, the small complement of fighter aircraft carried by these platforms

\footnotetext{
${ }^{73}$ James Jay Carafano, 'Measuring Military Power,' Strategic Studies Quarterly 8/ 3 (Fall 2014), 15-16; Ashley J. Tellis et al., Measuring National Power in the Postindustrial Age (Santa Monica, CA: RAND 2000), 138-41; Congressional Budget Office, Assessing the NATO/Warsaw Pact Military Balance (Washington DC: US GPO 1978), 53.

${ }^{74}$ Prior study has found that so-called symmetrical counting of military forces greatly affects public assessments of military balances. CBO, Assessing the NATO/Warsaw Pact Military Balance, 54.

${ }^{75}$ For a similar assessment, see Christopher Clary, 'Deterrence Stability and the Conventional Balance of Forces in South Asia,' in Krepon and Thompson, Deterrence Stability and Escalation Control in South Asia, 143-5.

${ }^{76}$ John Mearsheimer, The Tragedy of Great Power Politics (New York: W.W. Norton 2001), 88-9.

${ }^{77}$ Ibid., 89.

${ }^{78}$ Walter C. Ladwig III, 'Drivers of Indian Naval Expansion,' in Harsh V. Pant (ed.), The Rise of the Indian Navy: Internal Vulnerabilities, External Challenges (Farnham, UK: Ashgate 2012), 33.
} 
provides only a limited land-attack capability. ${ }^{79} \mathrm{With}$ respect to strikes by surface ships, the relatively short range of the BraMos and Klub cruise missiles (less than $290 \mathrm{~km}$ ) would expose attacking vessels - which possess only a moderate level of fleet air defense capability to Pakistan's ground-based aircraft. ${ }^{80}$

A blockade strategy -which attempts to coerce an opponent by cutting off its overseas trade or access to critical imports like oil -is also unlikely to have a meaningful impact in the scenarios we are considering. The advantages that land-based air forces have over surface navies has rendered the close blockade -where enemy warships are stationed just off shore $-\mathrm{a}$ relic of the nineteenth century and India's anemic submarine fleet lacks the ability to close Pakistan's ports on their own. ${ }^{81} \mathrm{~A}$ distant blockade astride Pakistan's major sea lanes is possible, however, the operational challenges of embargoing its maritime traffic are greater today than they were in the past. Although the twin ports of Karachi and Qasim still account for 90per cent of the country's trade, there are several other ports along the Makran coast that would also have to be accounted for most notably the new port of Gwadar which has been built with Chinese assistance near the Iranian border. This requires the Indian Navy to monitor more than $600 \mathrm{~km}$ of coastline, some of which is in the vicinity of one of the busiest shipping lanes in the world. In this environment, the nature of modern commerce makes it difficult to discriminate between Pakistan-bound traffic and neutral vessels. Shipments of both manufactured goods and raw materials can be bought and sold many times in the course of a journey, making it hard to determine the ultimate destination of a ship or its goods long before it arrives in port. ${ }^{82}$ Moreover, much of the shipping will not be carried out by Pakistani-flagged vessels, but that of third parties whose governments may strenuously object to having their property interdicted, boarded and searched by the Indian Navy. Will the Indian government be willing to provoke a diplomatic row in the midst of a clash with Pakistan? Some observers suggest that it is not necessary for the Indian Navy to actually interfere with foreign shipping: an announced blockade or the threat of force may be sufficient to drive insurance rates so

\footnotetext{
${ }^{79}$ James Holmes et al., Indian Naval Strategy in the Twenty-First Century (London: Routledge 2009), 86-7.

${ }^{80}$ Ladwig, 'Drivers of Indian Naval Expansion,' 34, 37. On the advantages of landbased air forces versus surface navies, see Mearsheimer, The Tragedy of Great Power Politics, 89.

${ }^{81}$ On the state of India's submarine fleet, see Iskander Rehman, 'The Indian Navy Has a Big Problem: The Subsurface Dilemma,' The National Interest, 4 Nov. 2014, <http:// nationalinterest.org/feature/the-indian-navy-has-big-problem-the-subsurface-dilemma$11598>$.

${ }^{82}$ Sean Mirski, 'Stranglehold: The Context, Conduct and Consequences of an American Naval Blockade of China,' Journal of Strategic Studies 36/ 3 (June 2013), 397.
} 
high that merchant ships choose to stay away from Pakistan. ${ }^{83}$ However, past experience does not necessarily suggest that merchants would be deterred by higher insurance rates. Several hundred merchant ships were attacked in the Persian Gulf during the so-called 'Tanker War' between Iran and Iraq (1981-88), yet merchant traffic was not substantially reduced. In fact, despite increased insurance rates, the shipping companies involved made substantial profits by operating in a danger zone, as did their counterparts who continued to sail to belligerent countries during World War I and World War II. ${ }^{84}$ Finally, it should be noted Pakistan has taken active steps to reduce its vulnerability to a naval blockade, most notably increasing its strategic oil reserves from seven days in 1999 to approximately 30 days of reserves today. ${ }^{85}$

Irrespective of whether or not the Indian Navy could sustain a blockade so far away from home, a future conflict between India and Pakistan is unlikely to last long enough for an embargo to have a meaningful effect. Past wars between the two countries have been comparatively short, with fighting lasting between two-weeks in 1971 and two months in 1999. A future clash is likely to be on the shorter end of that range since the Indian Army reportedly does not possess enough ammunition for a conflict lasting longer than three weeks. ${ }^{86}$ Moreover, recent crises in Indo-Pak relations have triggered political intervention by the US and other major powers, which would further limit the expected duration of an armed clash. ${ }^{87}$ Blockades, other the other hand -whose historical impact on the course of a conflict is often quite limited -require much longer than a few weeks or months to have an impact. ${ }^{88}$ Indeed, as one assessment notes, 'history indicates the improbability of conducting an embargo that has an immediate effect or attains decisive results by itself within a few months. ${ }^{89}$

\footnotetext{
${ }^{83}$ The author thanks Anit Mukherjee for raising this point.

${ }^{84}$ Michael A. Glosny, 'Strangulation from the Sea? A PRC Submarine Blockade of Taiwan,' International Security 28/ 4 (Spring 2004), 148.

${ }^{85}$ 'Pakistan Imports Crude Oil Worth \$15 billion,' The News, 30 Jan. 2014.

${ }^{86}$ Rajat Pandit, 'Army's Ammunition Won't Last 20 Days of War,' Times of India, 25 Aug. 2014.

${ }^{87}$ For a discussion of external crisis-management in recent episodes, see P.R. Chari et al., Four Crises and a Peace Process: American Engagement in South Asia (Washington DC: Brookings Institution Press 2007); Polly Nayak and Michael Krepon, The Unfinished Crisis: US Crisis Management after the 2008 Mumbai Attacks (Washington DC: Henry L. Stimson Center 2012).

${ }^{88} \mathrm{On}$ the questionable effectiveness of blockades historically, see Lance E. Davis and Stanley L. Engerman, Naval Blockades in Peace and War: An Economic History Since 1750 (Cambridge: CUP 2006).

${ }^{89}$ Robert A. Doughty and Harold E. Raugh, 'Embargoes in Historical Perspective,' Parameters 21 (Spring 1991), 28-9. See also, Glosny, 'Strangulation from the Sea?' 146-7.
} 
India's ability to economically coerce Pakistan via a naval blockade over a protracted period of time remains unclear, however, such an effort will not generate results in time to have a meaningful impact on the limited war scenarios considered here.

\section{Airpower}

The air-to-air balance between India and Pakistan is a sensible place to begin our analysis since airpower is a core component of the two limited aims strategies, either as a key enabler of a short ground offensive to seize territory or as a stand-alone tool for conducting strikes against ground-based targets across the border. The experience of modern militaries in war since 1991 has created the impression in both military and academic spheres that modern airpower is a truly transformative capability. Indeed, some analysts of South Asian security have suggested that of the differences in military capacity, India's superiority in airpower 'is the most serious for conventional military and nuclear instability. 90 However, there is good reason to believe that in a limited war to seize territory, the impact of advanced airpower on a ground battle will be less decisive.

Given that in the most likely war scenarios India will not achieve strategic surprise, a sudden preemptive airstrike that would destroy a large portion of the Pakistani Air Force (PAF) on the ground is unlikely. Instead, the Indian Air Force (IAF) would either have to concentrate its assets on achieving air superiority before initiating ground operations or contend with the PAF while simultaneously providing close air support (CAS) to ground forces. However, the latter mission is not necessarily one that the IAF has strongly embraced and based on recent experience there are good reasons to believe that the ability of aircraft to target defenders in well-prepared fighting positions, even with precision guided munition (PGMs) is limited. ${ }^{91}$

On an aggregate basis, the Indian Air Force has a 1.9:1 advantage over the Pakistan Air Force possessing 881 combat aircraft to its smaller neighbor's $450 .{ }^{92}$ However, the capability gap between the two fleets is best understood by looking not at the total number of aircraft, but at the number of high-performance aircraft in the fleet. If we define modern aircraft broadly to include all fighter aircraft of at least fourth generation -which are multi-role fighters of 1970 s or later design

\footnotetext{
${ }^{90}$ Jones, 'Conventional Military Imbalance and Strategic Stability in South Asia,' 29.

${ }^{91}$ Lambeth, 'Airpower in India's 1999 Kargil War,' 304.

${ }^{92}$ IISS, The Military Balance 2015, 251, 278.
} 
equipped with phisticated avionics and weapon systems -the picture looks somewhat worse for Pakistan. In early 2014, the Indian Air Force possessed 327 fighters of fourth generation or better in its fleet: $215 \mathrm{Su}$ 30MkI 'Flankers', 62 MiG-29 'Fulcrums' and 50 Mirage-2000s. In contrast, the Pakistan Air Force has 76 F-16s of various types as well as $50 \mathrm{JF}-17 \mathrm{~s}$ which are a 4th generation aircraft jointly produced by Pakistan and China. The Indian Air Force's superiority in modern aircraft presently stands at 2.6:1; however, Pakistan has managed to narrow this gap from the $4: 1$ differential that prevailed in the early 2000s (see figure 1).

Both the IAF and the PAF are seeking to expand their complement of modern aircraft in the coming decade. The Indian Ministry of Defence (MoD) plans to purchase 126 Dassault Rafale as part of its Medium Multi-Role Combat Aircraft (MMRCA) acquisition. However, the contract has been bogged down in protracted negotiations for the past two years. If the two sides succeed in finishing the deal by mid 2015, the first 18 planes would join the IAF in 2016, and the remainder would be built in India by Hindustan Aeronautics (HAL) commencing in $2018 .^{93}$ At the same time, the long-delayed, indigenously produced 4th generation HAL Tejas light-weight fighter is inching its way towards Final Operational Clearance in mid-2015. This could mean that the first squadron of an estimated 200 aircraft would be available in 2017-18, with approximately eight new fighters delivered each year after that. ${ }^{94}$ Across the border, the Pakistan Air Force has an additional $150 \mathrm{JF}-17 \mathrm{~s}$ on order, which will be equipped with even more advanced radars, weapons systems and avionics than its current versions of the aircraft.

If all of these acquisition plans stay on schedule -which is never a safe assumption -the Pakistan Air Force would be expected to shrink the gap in modern aircraft to less than $2.4: 1 .^{95} \mathrm{~A}$ principal advantage for Pakistan is that the JF-17 is already in production and aircraft are being delivered on a regular basis whereas India's acquisitions continue to suffer delays. Should these problems persist for the IAF, Pakistan might

\footnotetext{
${ }^{93}$ Rajat Pandit, 'MMRCA Deal: Rafael Negotiations Expected to be Wrapped Up in 3 Months,' Times of India, 3 June 2014; Rajat Pandit, 'Amid Sniping by Rivals, France Aims to Close Rafael Deal by Early 2015,' Times of India, 30 Oct. 2014.

${ }^{94}$ Ajai Shukla, 'First Tejas Rolls Out,' Business Standard, 3 Oct. 2014; 'Delay in LCA Project,' Business Standard, 25 Nov. 2014.

${ }^{95}$ India has pinned its hopes for a next generation fighter aircraft on a joint development project with Russia, but technical problems, disagreements over designs and delays have seen the potential of 220 Perspective Multi-Role Fighters (based on Sukhoi's PAK-FA) cut to 130 . The earliest India would start to take delivery of these aircraft, if the deal comes to fruition, is 2024-25. As a result, they are not included here. Rahul Bedi, 'Indian Air Force Unhappy at Progress of PAK-FA Fifth-Gen Fighter,' Jane's Defence Weekly, 4 Sept. 2014.
} 


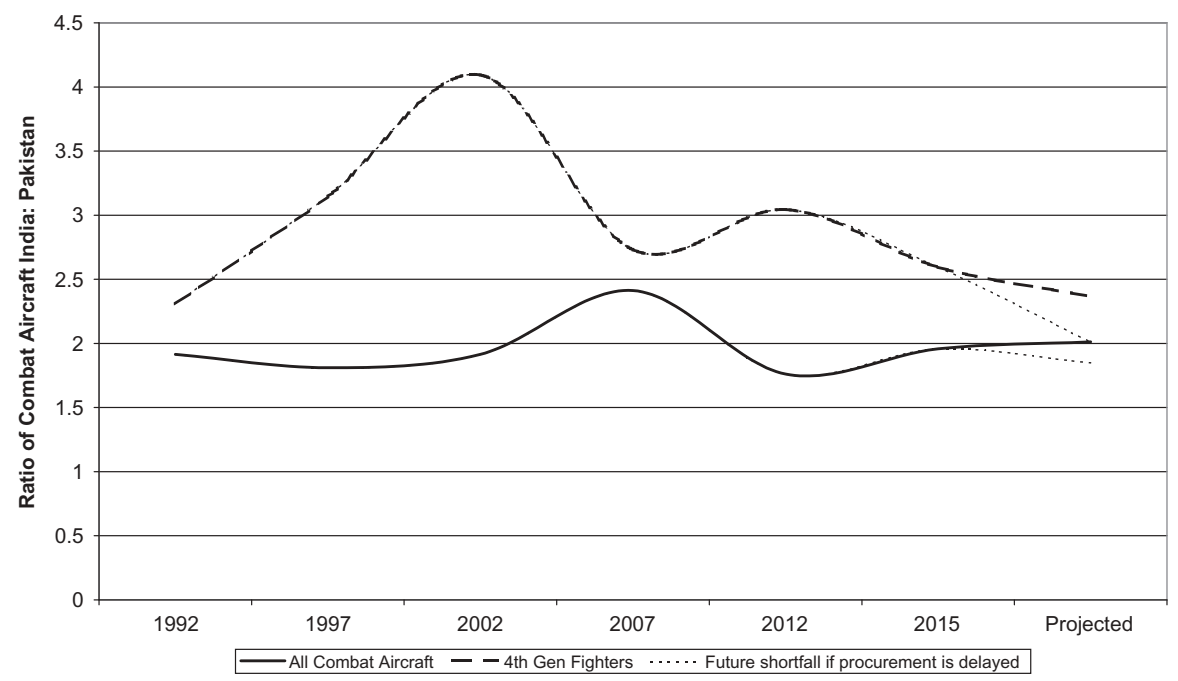

Figure 1. Combat Aircraft Balance 1992-2015.

Source: Data taken from various editions of the International Institute for Strategic Studies, Military Balance.

be expected to further reduce the gap to something approaching a postCold War low of $2: 1 .^{96}$ With procurement trends in the past decade appearing to favor the PAF, some observers have suggested that to leverage the potential of advanced sensors and precision-guided munitions the Indian Air Force needs to increase its number of modern fighter aircraft by 80 per cent. ${ }^{97}$

In terms of airborne early warning capability (AEW) the two air forces are fairly evenly matched. The IAF possesses three Israelidesigned Il-76TD Phalcon platforms and two converted Brazilian Embraer which functions as mini-Airborne Warning and Control System. Pakistan's AEW capability suffered a major blow in late 2012 when an attack on the Minhas air base by the Pakistan Taliban resulted in the destruction of a Swedish-made Saab 2000 Erieye and heavy damage to two others. ${ }^{98}$ The PAF has a fourth Erieye in service as well as two Chinese ZDK-03s, with a third on order. ${ }^{99}$ Although the technical specifications of the Indian platforms are superior, in practical terms both air forces now have a viable electronic warfare capability that is suited to their needs. The longer range of Indian radar systems is

\footnotetext{
${ }^{96}$ Assuming delays result in an effective 'loss' of 30 per cent of aircraft availability.

${ }^{97}$ Bakshi, 'Restructuring the Indian Armed Forces,', 26.

${ }^{98}$ 'Need a Fix' Defense Industry Daily, 21 March 2013, <www.defenseindustrydaily. com/sweden-finalizes-saab-2000-aewc-contract-with-pakistan-02377>.

${ }^{99}$ IISS, The Military Balance 2015, 251, 279.
} 
balanced by the fact that the IAF has significantly more territory to monitor than the PAF does. Due to the inferior radar systems on PAF fighters, the introduction of AEW aircraft benefits Pakistan — which can now detect the launch of fighter aircraft $240 \mathrm{~km}$ or more into Indian airspace while its AEW \&C aircraft are safely positioned deep within its own territory -relatively more than India.

\section{Ground Forces}

Despite India's on-going military modernization, Pakistan has managed to maintain an impressive conventional ground capability that possesses the advantage of shorter lines of communications, as well as prepared fighting positions that leverage natural and man-made obstacles to protect defensive forces. Although the overall force balance has remained relatively static over the past two decades, Pakistan has actually managed to erode its larger neighbor's advantages in some key areas such as number of tanks.

Since the end of the Cold War, the manpower balance between the two armies has hovered around a 2:1 ratio in India's favor, with approximately 1,150,900 soldiers in the Indian Army in 2015, compared to 550,000 in the Pakistani Army. Prior research on conventional deterrence indicates that the aggregate military balance is less important to the attacker's assessment of his ability to achieve a quick victory than the immediate correlation of forces in the theater of conflict. ${ }^{100}$ In this respect, it is important to remember that the full weight of the Indian Army is not on the border with Pakistan. Nine of the Army's 36 divisions (25per cent) are located in the east of the country, oriented towards the borders with China, Bangladesh or Burma. A total of 18 divisions (50per cent) are stationed in the states bordering Pakistan (Gujarat, Rajasthan, Punjab and Jammu and Kashmir). Importantly, 15 of these are infantry divisions, with only limited offensive power. ${ }^{101}$ The country's armored formations are primarily based in central India, a significant distance from the international border. ${ }^{102}$ On the other side of the border, 18 of the Pakistan Army's 22 divisions -including both of their armored divisions -are deployed in provinces adjacent to

\footnotetext{
${ }^{100}$ Paul K. Huth and Bruce Russett, 'What Makes Deterrence Work? Cases from 1900 to 1980,' World Politics 36/ 4 (July 1984), 496-526; Jack S. Levy, 'Quantitative Studies of Deterrence Success and Failure,' in Paul C. Stern et al. (ed.), Perspectives on Deterrence (New York: OUP 1989), 98-133

${ }^{101}$ The 1st Armoured Division is based in the Punjab and the 18th and 24th RAPID divisions -which are essentially infantry divisions with an additional mechanized brigade -are based in Rajasthan.

${ }^{102}$ Ladwig, 'A Cold Start for Hot Wars?' 160.
} 
the international border. That would provide a rough 1:1 balance of forces in the immediate theater at the start of any crisis. If we take into account the estimated 70,000 Pakistani soldiers that have been temporarily redeployed to the Afghan border to confront the Pakistani Taliban, India's manpower advantage at the theater level would be $1.2: 1 .^{103}$

Given the previously discussed advantages that accrue to defenders fighting from prepared positions, the conventional wisdom amongst some defense analysts and military planners is that an attacking force requires a 3:1 superiority in offensive strength at the tactical level as a requirement for successful breakthrough operations. ${ }^{104}$ At the theater level this translates into a need for a minimum of a 1.5:1 superiority in forces. However, analysts note that an attacker would likely seek a larger advantage, on the order of $2: 1$, before initiating offensive operations and those seeking a decisive outcome would want still higher force ratios in their favor. ${ }^{105}$ In any instance, the margin of India's local force advantage is not decisive. ${ }^{106}$

Although in a longer conflict India could bring its numerical superiority to bear, the military has numerous shortfalls of armament and equipment that make a protracted struggle unlikely. For example, as of August 2014, the Army lacked ammunition to undertake more than 20 days of 'intense fighting' with less than seven days of reserves of key stocks of artillery ammunition, anti-tank missiles and a 'critical shortage' of ammunition for its main battle tanks that would run out after ten days, hardly enough time for additional forces to make a difference. ${ }^{107}$

\footnotetext{
${ }^{103}$ Viola Gienger, 'Pakistan Pledges to Attack Al-Qaeda "Epicenter of Terrorism," Mullen Says,' Bloomberg, 14 Oct. 2010.

${ }^{104}$ This was the subject of considerable academic debate in the late 1980s, see for example John J. Mearsheimer, 'Assessing the Conventional Balance: The 3:1 Rule and Its Critics,' International Security, 13/ 4 (Spring 1989), 54-89 and T.N. Dupuy, 'Combat Data and the 3:1 Rule,' International Security 14/ 1 (Summer 1989), 196.

${ }^{105}$ Paul K. Davis, Aggregation, Disaggregation and the 3:1 Rule in Ground Combat (Santa Monica, CA: RAND 1995), 15-16.

${ }^{106}$ For studies reaching a similar conclusion, see Khurshid Khan, Limited War under the Nuclear Umbrella and Its Implications for South Asia (Washington DC: Henry L. Stimson Center May 2005),. 21; Arzan Tarapore, Holocaust or Hollow Victory: Limited War in Nuclear South Asia,' IPCS Research Papers, No. 6 (New Delhi: Institute of Peace and Conflict Studies, Feb. 2005), 16; and Clary, 'Deterrence Stability and the Conventional Balance of Forces in South Asia,' 160.

${ }^{107}$ Pandit, 'Army's Ammunition Won't Last 20 Days of War;'; 'Only Ten Days of Ammunition Left?' Zeenews Bureau, 6 April 2012; Sharma and Datt, 'Parliamentary Standing Committee on Defence Admits Shortage of Ammunition.'
} 


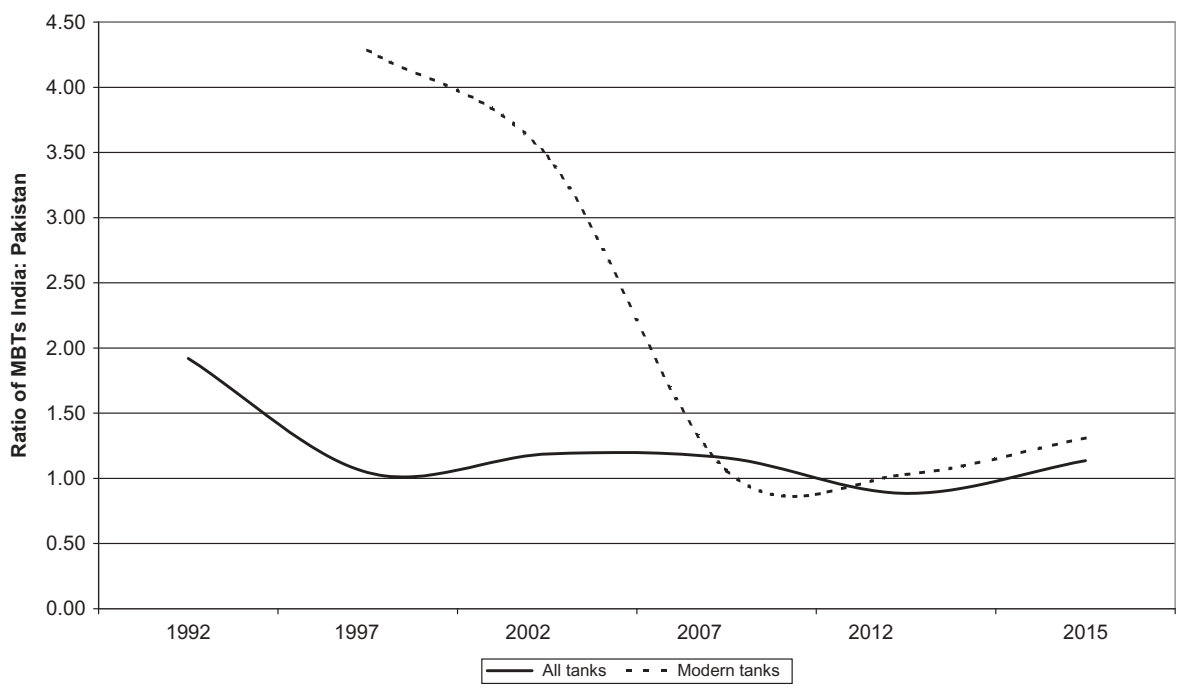

Figure 2. Main Battle Tanks 1992-2015.

Source: Data taken from various editions of the International Institute for Strategic Studies, Military Balance.

In terms of equipment for ground combat, Pakistan appears to have partially closed a nearly 2:1 gap in tanks that India possessed in the early $1990 \mathrm{~s}$, to the point where India's advantage is just over 1.1:1. ${ }^{108}$ Large numbers of tanks on both sides are vintage second-generation platforms. If we focus on modern high-performance main battle tanks (MBT), such as the third generation T-80UDs and Al-Khalids fielded by Pakistan or India's own T-90 and Arjun tanks, India again possesses a slight (1.3:1) advantage in numbers (924 v. 705). However, this edge is undercut by the aforementioned fact that Pakistani armored units are primarily stationed in the vicinity of the international border, while India's are primarily based in central India. Moreover, it is alleged that majority of the Army's fleet of tanks are unable to operate at night and many are nearing obsolescence, while large numbers of their modern replacements are unsuited for operations in the heat and dust of the desert regions around the international border. ${ }^{109}$ Unsurprisingly, Indian defense analysts argue

\footnotetext{
${ }^{108}$ This is a count of tanks on active service; it does not include vehicles in long-term storage.

${ }^{109}$ Kanwal, 'India's Military Modernization,' 3; Rahul Bedi, 'Government Auditor Slams Indian Army for T-90s Air-Conditioning Failures,' Jane's Defence Weekly, 24 Feb. 2014.
} 
that their army requires at least 1,500 modern tanks to gain a conventional edge. ${ }^{110}$

The major shortcoming for Indian forces seeking to undertake a short-notice offensive is their lack of mobile artillery to provide fire support to advancing units. As one damning assessment notes the Army '... lacks towed and self-propelled $155 \mathrm{~mm}$ howitzers for the plains and the mountains and has little capability by way of multi-barrel rocket launchers and surface-to-surface missiles. ${ }^{111}$ Political scandals and bureaucratic red tape have left the Army with just 10per cent of the self-propelled artillery its mobile armored brigades and divisions require, constraining the kind of bold thrusts a 'limited aims' offensive would require. ${ }^{112}$ In total, the Indian Army has a shortfall of more than 1,600 howitzers, self-propelled guns and towed artillery pieces. ${ }^{113} \mathrm{~A}$ recently announced plan to acquire 814 mounted gun systems will address some of this shortfall, but the byzantine nature of Indian weapons procurement and a history of repeated artillery acquisition failures makes it unknown when, if ever, these weapons will actually find their way into service. ${ }^{114}$ Additionally, it appears that India's existing artillery assets have experienced widespread obsolescence. A scathing report by the Comptroller and Auditor General's office finds that artillery regiments possess 'a mix of various gun systems whose technology ranges from World War II to those developed in the seventies. ${ }^{115}$ In contrast, Pakistan possesses 25 times the number of self-propelled guns as India does -admittedly not as important for defensive operations as it is for offense.

The salient point to take away is that the aggregate military balance between India and Pakistan is significantly greater than the ratio of forces that can quickly be brought to bear in a short-notice conflict. While Pakistani forces are stationed closed to their defensive fighting positions, the Indian Army's primary offensive capability is concentrated in Central India, a significant distance from the international

\footnotetext{
${ }^{110}$ Gurmeet Kanwal, Indian Army Modernization Needs a Major Push (New Delhi: India Strategic, Feb. 2010), 2-3.

${ }^{111}$ Kanwal, 'India's Military Modernization,' 3.

${ }^{112}$ There have not been any procurements of self-propelled artillery since 2005. John H. Gill, 'India and Pakistan: A Shift in the Military Calculus?', in Ashley J. Tellis and Michael Wills (ed.), Strategic Asia, 2005-06: Military Modernization in an Era of Uncertainty (Seattle, WA.: National Bureau of Asian Research 2005), 244.

${ }^{113}$ Comptroller and Auditor General (hereafter CAG), Report No. 24: Union Government (Defence Services) Army and Ordnance Factories, Dec. 2011, 12.

${ }^{114}$ Pranav Kulkarni, 'Manohar Parrikar Greenlights Purchase of 814 Artillery Guns,' Indian Express, 23 Nov. 2014; 'Structural Problems and Lack of Transparency Continue to Plague India's Arms Procurement Policy,' DNA India, 3 Jan. 2014.

${ }^{115}$ CAG, Report No. 24, 12.
} 
border. Those Indian forces that are based in close proximity to the border are infantry-heavy units, primarily designed to halt or contain an enemy attack, not undertake offensive operations. Moreover, the force as a whole possesses critical shortfalls in areas like mobile fire support. Based on the aftermath of the 2001 and 2008 terrorist attacks, the Indian Army would require several weeks before it could hope to initiate military operations, if it could undertake them at all. ${ }^{116}$ India's overall manpower advantages are only likely to have an impact in a very long war with Pakistan of the type that has been prevented from occurring in recent years by great power intervention, and is beyond the ability of the military's munitions stocks to sustain.

\section{Examining the Scenarios}

How will the environmental and geographic factors interact with the available forces in the two limited war scenarios? Is conventional deterrence likely to hold or will Indian policymakers have a high degree of confidence that they can obtain their objectives through the use of force?

\section{Limited War (Territory)}

In the mid-2000s, the Indian Army began exploring changes to its force structure and concept of operations to enable short-notice offensives that would seek to make several small thrusts to Pakistan to quickly seize and hold territory. This proactive strategy, sometimes referred to as 'Cold Start' has never been officially adopted by the Indian Army but it has been tested in numerous wargames since 2004 and appears to drive the service's procurement and modernization strategy. ${ }^{117}$ If the Indian Army were to contemplate a limited aims offensive against Pakistan with the purpose of seizing a section of territory, a Cold Start-like offensive would be the way it went about it. Such an undertaking would have both air and ground components, which are examined in turn.

Air Component The quantitative superiority of the IAF would likely translate into dominance over the PAF in a protracted conflict; however, in a shorter-duration clash India will not necessarily be able to reap all of the advantages of its greater number of modern fighters. In the kind of scenarios examined here, not all of India's front-line aircraft can be deployed against Pakistan: some will have to remain along the

\footnotetext{
${ }^{116}$ Unnithan, 'Not Ready for War.'

${ }^{117}$ For evidence that some efforts to implement a proactive strategy are underway, see Cohen and Dasgupta, Arming without Aiming, 61.
} 
Chinese border to ensure that Beijing does not try to relieve pressure on its 'all weather ally' or take advantage of a crisis to settle its own territorial disputes with India, while others may be constrained by the number of airbases within $1,000 \mathrm{~km}$ of the border region.

Given that the most likely triggers of conflict will eliminate strategic surprise, the IAF cannot hope to destroy the majority of the PAF on the ground in a surprise attack like Israel did to Egypt in 1967. Establishing the air superiority over Pakistan necessary to support ground operations will require the IAF to not only defeat PAF fighters in combat, but to suppress the country's modest air defense system. Pakistan's air defense systems are built around a Chinese variant of the $35 \mathrm{~km}$-ranged, high-altitude $(20 \mathrm{~km}) \mathrm{SA}-2$ Guideline and the $25 \mathrm{~km}-$ range low-to-medium altitude $(3.5 \mathrm{~km})$ MBDA Spada 2000 missile systems. These are supplemented by a host of mobile short-range tactical surface-to-air missiles that can strike targets from $5 \mathrm{~km}$ to $11 \mathrm{~km}$ away at altitudes from $3 \mathrm{~km}$ to $6 \mathrm{~km} .{ }^{118}$ Details about the exact configuration of Pakistan's air defense system are sensitive, however it appears that there is a single SA-2 site near Islamabad, with rumors of a second one positioned near Karachi, but it is unclear if this second site is active.

There are several factors that might impede the IAF's ability to provide effective air support to ground operations. The first is its doctrinal and organizational bias against close air support (CAS). Like many air forces around the world, the IAF is hesitant to embrace CAS as a priority mission, focusing instead on air-to-air combat and strategic bombing. ${ }^{119}$ In fact, the idea of tightly coordinated airground operations runs counter to the Indian Air Force's own concept of joint operations, which involves the services fighting wars separately but according to a coordinated plan. ${ }^{120}$ The IAF believes that attaching aircraft to specific ground units in a defined geographic space as the Army prefers is a fundamental misuse of airpower that fails to leverage the Air Force's numerical superiority over its Pakistani counterparts. As a result of this lack of attention to CAS, when pressed into service, the IAF's results at the tactical level have been less than desired. In the 1999 Kargil War, for example, the IAF had great difficulty targeting Pakistani forces who were dispersed and dug in to

\footnotetext{
${ }^{118}$ The primary systems are the Bofors RBS 70, the Crotale 4000, and the MBDA Mistral.

${ }^{119}$ Pinaki Bhattacharya, 'Army and IAF Face Off over New War Plan,' India Today, 14 Dec. 2009.

${ }^{120}$ Y. I. Patel, 'Dig Vijay to Divya Astra - a Paradigm Shift in the Indian Army's Doctrine,' Bharat Rakshak Monitor 6/ 6 (May/June 2004).
} 
complex terrain, as they would be in their defense along the international border. ${ }^{121}$

Lack of peacetime focus on close air support and joint operations with the Army has also created difficulties at the operational level. As a result of their different conceptions of how airpower should be deployed, at the start of the Kargil conflict, senior officers from the Indian Army and Air Force squandered two weeks arguing about the nature and extent of air support that should be provided to ground troops who were fighting Pakistani infiltrators. ${ }^{122}$ Interservice coordination is not something that can be willed into place in a crisis, it is the result of training and experience. In 2011, for the first time in four years, the Indian Army and Air Force undertook large-scale joint exercises to practice integrating air-land war fighting. ${ }^{123}$ These were followed up by similar corps-level exercises in $2012 .{ }^{124}$ In previous joint exercises, the Army and Air Force operated sequentially rather than in concert - failing to integrate their efforts or demonstrate a high degree of joint warfare capability. ${ }^{125}$ It is unclear how much success the services have had in, in solving this problem, however the Army's recent aggressive campaign to wrest control of all future attack helicopters from the Air Force suggest that significant coordination challenges remain. ${ }^{126}$

Although possessing clear limits to their capacity, Pakistani fighter and air defense capability is strong enough to frustrate Indian efforts to quickly gain the air superiority necessary to facilitate ground operations. Moreover, the ability of Indian airpower to effectively synchronize with ground elements will be hindered by internal organizational and bureaucratic impediments, raising questions about their ability to operate as highly mobile 'flying artillery.'

Ground Component With its military facilities and major lines of communication running so close to the border, Pakistan's long, slender shape is a vulnerability to a deep military thrust that seeks to sever the country in half. However, it is an advantage in responding to a crisis, since the Pakistani military has the ability to mobilize its forces much more rapidly than India does. In the absence of strategic surprise which is unlikely to occur given the most likely paths to war -the Indian

\footnotetext{
${ }^{121}$ Lambeth, 'Airpower in India's 1999 Kargil War,' 304.

${ }^{122}$ Ibid., 298, 308.

${ }^{123}$ 'Indian Army and Air Force Conduct Joint Exercise in Rajasthan,' DefenceNow, 11 May 2011.

124'Indian Army Summer Battle Exercise in Rajasthan,' DefenceNow, 28 April 2012.

${ }^{125}$ Ladwig, 'A Cold Start for Hot Wars?' 182.

${ }^{126}$ Josy Joseph, 'Army's Demand for Attack Choppers Triggers Fresh Turf War with IAF,' Times of India, 14 July 2012.
} 
Army's ability to overcome the Pakistani military's mobilization advantage via cutting edge military technology is limited. Unless it permanently bases offensive formations within striking range of the border, the best India could hope for is to achieve tactical surprise, which both restricts the range of objectives an attacker could hope to achieve before the defender responds and makes it much harder to avoid large-scale battle with the defensive forces. ${ }^{127}$

For the first several days of a limited conflict, tactical surprise might just about offset the terrain advantages accruing to Pakistani forces situated in rough terrain such as Kashmir. However, fighting from fortified positions would give them the equivalent strength of a force half-again their size. ${ }^{128}$ Further south, on the flat Punjab plain, Indian forces would face much better prospects; however, tactical surprise would still not fully cancel out the advantages of Pakistan's defensive fortifications. In a conflict of several weeks duration, India could leverage its larger numbers by shifting forces from East to West, but that would be beyond the short, sharp offensive envisioned under the limited aims offensive and could require a longer period of fighting than most analysts believe is possible before outside powers intervene to force a resolution to the crisis or the Indian Army runs out of ammunition. Moreover, a major shift of troops or the opening of multiple fronts beyond the LoC in Kashmir would signal to Pakistan that the conflict was not limited and short-duration, but full-scale war with the attendant nuclear escalation risks. Thus, under the most likely scenarios, India would have parity at best; if not actual disadvantages in the number of troops it could bring to bear in the early days of a conflict. None of this suggests Indian political leaders would have a high degree of confidence that a limited aims offensive would quickly achieve its objectives at minimal risk.

\section{Airstrikes}

A number of analysts consider airstrikes to be the most likely Indian response to a terrorist attack. ${ }^{129}$ This could either take the form of strikes on targets with manned aircraft or long-range cruise missiles. As noted previously, conventional deterrence is likely to fail in this scenario when Indian policymakers believe that rapid and decisive surgical

\footnotetext{
${ }^{127}$ On the inferiority of tactical surprise, see Mearsheimer, Conventional Deterrence, 54.

${ }^{128}$ Historically derived estimates of the impact of surprise, terrain and defensive fortifications in this section are drawn from Dupuy, Attrition, 146-52.

${ }^{129}$ See, for example, George Friedman, 'Next Steps in the Indo-Pakistani Crisis,' Stratfor, 8 Dec. 2008; Markey, 'Terrorism and Indo-Pakistani Escalation,' 2.
} 
strikes are possible and that they will not trigger an escalation of the conflict to full-blown war.

The IAF's advanced fighter aircraft have the capability to carry out cross-border strikes. Of course such operations are far from riskless since, as described for the air component of the limited aims ground offensive above, manned air strikes on targets in Pakistan or Pakistanadministered Kashmir would have to contend with alerted Pakistani fighter aircraft and air defenses. A second potential limitation is the depth of the IAF's arsenal of precision-guided munitions. Such weapons have been employed selectively in the past, but recent analysis suggests it would be another 5-10 years before they are commonplace. ${ }^{130}$ One option for reducing the risk of such a venture is to employ cruise missiles -like the $290 \mathrm{~km}$-range supersonic BraMos missile or the $1,000 \mathrm{~km}$ range Nirbhay currently undergoing testing -instead of manned aircraft.

The problem facing a bombardment strategy is that achieving a 'decisive' result and limiting escalation are necessarily in tension with each other: the targets that are of lowest risk for a limited aims strike are also those of least value. If India were to opt for attacks on 'high-value' militant assets in Pakistan proper, such as the Lashkar-e-Taiba's massive headquarters in Muridke, or, as some suggest, Inter-Services Intelligence facilities linked to terrorist groups, it may succeed in imposing significant costs on Islamabad and Rawalpindi, but a significant military response would be guaranteed. In contrast, the most 'limited' target available would be terrorist training camps in Pakistan-controlled Kashmir. However, these targets are likely to be unsatisfactory for several reasons. First, Kashmiri militant groups have diversified across Pakistan: Of 42 identified militant camps, the Indian government estimates that 40per cent are located in Pakistan proper, in areas like the Punjab, Sindh and Federally Administered Tribal Areas (FATA). ${ }^{131}$ Thus, there is no guarantee that the group suspected of responsibility for a specific terrorist attack would be vulnerable to retaliation in Pakistani Kashmir. Even if it were, it is not clear that such an action would achieve a meaningful result. ${ }^{132}$ Following news of a major terror attack in India, anti-Indian terrorist groups -even those unconnected to the event -are likely to go into hiding for a period of time, leaving identified camps unoccupied. Finally,

\footnotetext{
${ }^{130}$ Vivek Kapur, Transformation of the Indian Air Force over the Next Decade (New Delhi: Institute for Defence Studies \& Analysis, 13 June, 2012), 4.

${ }^{131}$ 'India Accuses Pakistan of Maintaining 'Militant Camps' Along Border,' The Express Tribune (Pakistan), 4 Dec. 2012.

${ }^{132}$ B. Raman, 'Make Them Pay,' Outlook, 23 Feb. 2010.
} 
the ability of airpower to significantly damage terrorist bases is open to question. Previous assessment of the effectiveness of American airstrikes against terrorist infrastructure in Libya (1986), Iraq (1993), and Sudan/Afghanistan (1998) judges that they had minimal impact, and failed to cripple the ability of the targeted groups to carry out or sponsor future acts of terrorism. ${ }^{133}$ From a technical standpoint, the Indian Air Force lacks strategic bombers capable of delivering a heavy payload over a large enough area to destroy a sizeable facility. The small payloads of Indian strike aircraft or cruise missiles are unlikely to be sufficient for the task.

It may be possible to reduce escalatory pressure on the Pakistani government by strictly confining bombardment to the disputed territory of Kashmir, avoiding a direct confrontation with Pakistani military assets, and inflicting very limited civilian casualties. Nevertheless, the Pakistani government will likely face strong domestic pressure -from both the military, radical Islamist groups, and a nationalistic public -to mount a response to an Indian attack. The optimistic case is that restricting the strikes to Pakistan administered Kashmir -rather than internationally recognized Pakistani territory -will prevent Pakistan from horizontally escalating the conflict beyond Kashmir, thus keeping the clash from escalating vertically into full-scale war. If this assumption holds, the PAF may confine itself to engaging Indian aircraft and retaliating against the airbases that launched them with bombs and missiles, confining the conflict to a series of tit-for-tat clashes. However, there are reasons to believe that Pakistan may not calibrate its response. As some analysts have argued, the Pakistani government could purposefully opt for a disproportionate retaliation 'so as to compel the international community to force a ceasefire.'134 This logic is recognized within certain circles of the Indian government. 'The idea that Pakistan will cooperate in a conflict and comply with India's wishes to fight a limited war is ridiculous,' an External Affairs Ministry official has noted, 'It will be naturally in [Pakistan's] interest to keep any conflagration as unlimited as possible.'135

\footnotetext{
${ }^{133}$ Michele L. Malvesti, 'Bombing Bin Laden: Assessing the Effectiveness of Air Strikes as a Counter-Terrorism Strategy,' The Fletcher Forum of World Affairs26/ 1 (Winter 2002),17-29.

${ }^{134}$ Dan Markey of the Council on Foreign Relations quoted in Anwar Iqbal, 'Pakistan's Response to Attack Will Be Intense, Says Report,' Dawn, 21 Jan., 2010. See also, Ajaya Kumar Das, 'Mumbai II? Why India Will Again Show Restraint,' RSIS Commentary, No. 130/2010 (13 Oct. 2010).

${ }^{135}$ Quoted in Sumit Ganguly and Michael R. Kraig, 'The 2001-2002 Indo-Pakistani Crisis: Exposing the Limits of Coercive Diplomacy,'Security Studies 14/ 2 (2005), 311.
} 
This discussion of escalatory risks has thus far focused on rational calculations by the two sides, but the fog of war can lead to misperception of an opponent's intentions and actions. Decisionmakers are often forced to provide direction on the basis of incomplete information. Even with modern surveillance and communications systems, organizational and cognitive factors can cause a misinterpretation of ongoing combat operations. This is particularly relevant when discussing bombardment since, as Indian Air Marshal Vinod Patney has noted, 'it is the nature of airpower that escalation is inherent in its use, unless its use is one-sided .... ${ }^{136}$ Recognition of the escalatory potential of airpower and the ease with which its use can be misperceived has led India and Pakistan to reach a formal agreement that military aircraft will not approach within $10 \mathrm{~km}$ of each other's airspace. ${ }^{137}$ This covenant was even honored during the 1999 Kargil War, where PAF fighters flew defensive patrols some distance away from the border during an active conflict, while the IAF accepted a significant degradation in the effectiveness of its strikes on Pakistani forces in Indian-administered Kashmir in order to avoid breaching the Line of Control. ${ }^{138}$

Limited strikes on a limited number of targets in Kashmir may prevent a conflict from escalating horizontally or vertically but, for reasons described above, this is likely to result in military action that is primarily symbolic, rather than substantive, in nature, designed to assuage the anger of the Indian public rather than inflict meaningful harm on terrorist networks. Thus, Indian policymakers will have to assess whether the largely symbolic gains likely to be achieved from such airstrikes are worth risking the risks of escalation. Experience from recent conflicts suggest that senior Indian military and political leaders have a high degree of risk aversion and are unlikely to favor actions that could trigger a major escalation during a crisis. ${ }^{139}$

\section{Assessment}

Neither of the two scenarios discussed here suggest that Indian policymakers, with whom the ultimate decision to use force rests, can be confident that they will achieve their political objectives through a limited use of force. Instead, the risks that such an action would either

\footnotetext{
${ }^{136}$ Quoted in Pushpindar Singh, Himalayan Eagles: History of the Indian Air Force (New Delhi: The Society for Aerospace Studies 2007), 108-9.

${ }^{137}$ India and Pakistan, 'Agreement on Advance Notice on Military Exercises, Maneuvers and Troop Movements,' 6 April 1991, UNTS No. 31420, <http://treaties. un.org/doc/publication/unts/volume\%201843/volume-1843-i-31420-english.pdf>.

${ }^{138}$ Lambeth, 'Airpower in India's 1999 Kargil War,'. 300-1.

${ }^{139}$ Iibid.,. 297-8.
} 
stalemate into a war of attrition or spiral into a larger conflict bolsters confidence in Pakistan's deterrent capability. Not only is the military capability that India can bring to bear in either type of limited aims offensive far less than the analysts who fret about Indian military modernization appreciate, irrespective of Indian military capabilities, structural and environmental factors such as the terrain, lack of strategic surprise, and the relative military prowess of the two sides will conspire to prevent India from achieving a quick, costless victory.

\section{Conclusion}

Headline grabbing increases in the Indian defense budget and a highprofile military modernization program have alarmed observers who worry that these developments could undermine the conventional military balance credited with maintaining 'ugly stability' in South Asia. While on their face these concerns have validity, upon deeper examination, there is still good reason to continue to be optimistic about the prospects for conventional deterrence. India's defense procurement continues to under perform, producing far less in terms of military power than its spending would suggest. Conversely, Pakistan -assisted by China and others -has prevented the emergence of sharp asymmetries in the conventional military balance and even narrowed previously existing gaps.

Modernizing or not, the Indian military is capable of bringing far less force to bear in a limited conflict with Pakistan than the pessimists realize. As a result, it is unlikely that Indian policymakers would conclude that they can either achieve strategic surprise against Pakistan or carry out highly-effective air strikes with little escalatory risk, each of which is a necessary condition for deterrence failure. Consequently, Pakistan's justification for its current efforts to develop tactical nuclear weapons and delivery systems on security grounds lacks a firm foundation. These systems only increase the likelihood of an inadvertent nuclear exchange, while adding little to the deterrence value of Pakistan's force posture. There may be a variety of reasons why Islamabad is expanding and diversifying its nuclear arsenal, but a rational response to the threat posed by India's on-going military modernization is not one of them. ${ }^{140}$

\footnotetext{
${ }^{140}$ For an argument that, apart from security concerns, nuclear proliferation can be driven by domestic politics or norms see Scott D. Sagan, 'Why Do States Build Nuclear Weapons?: Three Models in Search of a Bomb,' International Security. 21/ 3 (Winter 1996-97), 54-86.
} 


\section{Acknowledgements}

The author thanks Stephen Rosen, Paul Staniland, Vipin Narang, Christopher Clary, Nina Silove, Gaurav Kampani, Anit Mukherjee, Srinath Raghavan and the participants at the workshop on Indian Security at the Center for the Advanced Study of India, University of Pennsylvania for helpful comments on a prior draft of this article.

\section{Notes on contributor}

\section{Walter C. Ladwig III is an Assistant Professor of International Relations at King's College, London and a Visiting Fellow in South Asian Security at the Royal United Services Institution.}

\section{Bibliography}

Ahmed, Mansoor, 'Security Doctrines, Technologies and Escalation Ladders: A Pakistani Perspective' (paper presented at the US-Pakistan Strategic Partnership: A Track II Dialogue, Phuket, Thailand, 18-19 Sept. 2011).

Akram, Munir, 'Gambling Against Armageddon,' Dawn, 26 Oct. 2014.

Arquilla, John, 'Nuclear Weapons in South Asia: More May Be Manageable,' Comparative Strategy 16/1 (Jan.-March 1997), 13-31.

Bakshi, G.D., 'Restructuring the Indian Armed Forces,' Journal of Defence Studies 5/2 (April 2011), 26.

Bedi, Rahul, 'No Guns, No Glory,' Tehelka, 9/14 (7 April 2012).

Bedi, Rahul, 'Government Auditor Slams Indian Army for T-90s Air-Conditioning Failures,' Jane's Defence Weekly, 24 Feb. 2014.

Bedi, Rahul, 'Indian Air Force Unhappy at Progress of PAK-FA Fifth-Gen Fighter,'Jane's Defence Weekly, 4 Sept. 2014.

Bergen, Peter and Bruce Hoffman, Assessing the Terrorist Threat (Washington DC: Bipartisan Policy Center 10 Sept. 2010).

Bhattacharya, Pinaki, 'Army and IAF Face Off over New War Plan,' India Today, 14 Dec. 2009.

Biddle, Stephen, Afghanistan and the Future of Warfare: Implications for Army and Defense Policy, (Carlisle, PA: US Army War College, Nov. 2002).

Biddle, Stephen, 'Afghanistan and the Future of Warfare,'Foreign Affairs (March/April 2003), 31-46.

Biddle, Stephen, Military Power: Explaining Victory and Defeat in Modern Battle (Princeton UP 2004).

Biddle, Stephen, et al., Toppling Saddam: Iraq and American Military Transformation (Carlisle, PA: US Army War College, Strategic Studies Institute April 2004).

Biddle, Stephen, 'Allies, Airpower, and Modern Warfare: The Afghan Model in Afghanistan and Iraq,' International Security 30/3 (Winter 2005/06), 161-76.

Bracken, Paul, 'The Problem from Hell: South Asia’s Arms Race,' The Diplomat, 29 Nov. 2012.

Carafano, James Jay, 'Measuring Military Power,' Strategic Studies Quarterly 8/3 (Fall 2014), 11-18.

Chari, P.R. et al., Four Crises and a Peace Process: American Engagement in South Asia (Washington DC: Brookings Institution Press 2007).

Chellaney, Brahma, 'India's Missing Hard Power,' Mint, 21 April 2010.

Clary, Christopher and Vipin Narang, 'Doctrine, Capabilities, and (In)Stability in South Asia,' in Michael Krepon and Julia Thompson (eds), Deterrence Stability and Escalation Control in South Asia (Washington DC: The Stimson Center 2013). 


\section{Walter C. Ladwig III}

Clary, Christopher, 'Deterrence Stability and the Conventional Balance of Forces in South Asia,' in Krepon and Thompson, Deterrence Stability and Escalation Control in South Asia.

Clausewitz, Carl von, On War, trans. Michael Howard and Peter Paret (Princeton UP 1984).

Cohen, Eliot A., 'Change and Transformation in Military Affairs,' Journal of Strategic Studies 27/3 (Sept. 2004), 395-407.

Cohen, Stephen P., and Sunil Dasgupta, Arming without Aiming: India's Military Modernization (Washington DC: Brookings Institution Press 2010).

Comptroller and Auditor General, Report No. 24: Union Government (Defence Services) Army and Ordnance Factories, Dec. 2011.

Conference Report, 'Indian Military's Cold Start Doctrine and its Implications for Strategic Stability in South Asia' (Islamabad, Pakistan: South Asian Strategic Stability Institute, 20-22 July 2010).

Congressional Budget Office, Assessing the NATO/Warsaw Pact Military Balance (Washington DC: US GPO 1978).

Cordesman, Anthony H., Iraqi Military Forces Ten Years After the Gulf War (Washington DC: Center for Strategic and International Studies Aug. 2000).

Cotta-Ramusino, Paolo, and Maurizio Martellini, 'Nuclear Safety, Nuclear Stability, and Nuclear Strategy in Pakistan: A Concise Report of a Visit by Landau Network-Centro-Volta' (Como, Italy: Landau Network, Jan. 2001).

Countries Should Commit to No-First-Use Policy,' Express Tribune, 16 May 2014.

Dalton, Toby, and Jaclyn Tandler, Understanding the Arms 'Race' In South Asia (Washington DC: Carnegie Endowment for International Peace, Sept. 2012).

Daniel, Frank, 'Kashmir Shelling, Spat Over Pak Aid Mar Run-up to Kerry Trip,' Reuters, 6 Jan. 2015.

Das, Ajaya Kumar, 'Mumbai II? Why India Will Again Show Restraint,' RSIS Commentary, No. 130/2010 (13 Oct. 2010).

Davis, Paul K., Aggregation, Disaggregation and the 3:1 Rule in Ground Combat (Santa Monica, CA: RAND 1995).

Davis, Lance E. and Stanley L. Engerman, Naval Blockades in Peace and War: An Economic History Since 1750 (Cambridge: CUP 2006).

'Delay in LCA Project,' Business Standard, 25 Nov. 2014.

Desch, Michael C., Power and Military Effectiveness: The Fallacy of Democratic Triumphalism (Baltimore, MD: Johns Hopkins Press 2010).

Doughty, Robert A. and Harold E. Raugh, 'Embargoes in Historical Perspective,' Parameters 21 (Spring 1991), 28-9.

Dupuy, Trevor N., 'Combat Data and the 3:1 Rule,' International Security 14/1 (Summer 1989), 195-201.

Dupuy, Trevor N., Attrition: Forecasting Battle Casualties and Equipment Losses in Modern War (Falls Church, VA: Nova Publications 1995).

Farooq, Agha Umer, 'Deterrence Stability, Security Doctrines \& Escalation Control in South Asia,' (paper presented at the US-Pakistan Strategic Partnership: A Track II Dialogue, Phuket, Thailand, 18-19 Sept. 2011).

'50 Pakistan-assembled JF-17 Fighter Jets Inducted into PAF,' The Express Tribune, 2 Dec. 2014.

Fitchett, Joseph, 'NATO Misjudged Bombing Damage,' International Herald Tribune, 23 June 1999.

Flory, Keith, 'Military Muscle,' Statesman, 20 May 2002.

Fortmann, Michel and Stefanie von Hlatky, 'The Revolution in Military Affairs: Impact of Emerging Technology on Deterrence,' in T.V. Paul, Patrick M. Morgan, and James J. Wirtz (eds), Complex Deterrence: Strategy in the Global Age (Univ. of Chicago Press 2009).

Friedman, George, 'Next Steps in the Indo-Pakistani Crisis,' Stratfor, 8 Dec.2008.

Ganguly, Sumit, Conflict Unending: India-Pakistan Tensions Since 1947 (New York: Columbia UP 2001). 
Ganguly, Sumit and Michael R. Kraig, 'The 2001-2002 Indo-Pakistani Crisis: Exposing the Limits of Coercive Diplomacy,' Security Studies 14/2 (2005), 290-324.

Geller, Daniel S., and J. David Singer, Nations at War: A Scientific Study of International Conflict (Cambridge: CUP 1998).

Gienger, Viola, 'Pakistan Pledges to Attack Al-Qaeda “Epicenter of Terrorism”,' Mullen Says,' Bloomberg, 14 Oct. 2010.

Gill, John H., 'India and Pakistan: A Shift in the Military Calculus?', in Ashley J. Tellis and Michael Wills (ed.), Strategic Asia, 2005-06: Military Modernization in an Era of Uncertainty (Seattle, WA: National Bureau of Asian Research 2005), 237-268.

Gill, John H., 'Military Operations in the Kargil Conflict,' in Peter R. Lavoy (ed.), Asymmetric Warfare in South Asia: The Causes and Consequences of the Kargil Conflict (Cambridge: CUP 2009), 92-129.

Glosny, Michael A., 'Strangulation from the Sea? A PRC Submarine Blockade of Taiwan,' International Security 28/4 (Spring 2004), 125-60.

Grauer, Ryan and Michael C. Horowitz, 'What Determines Military Victory? Testing the Modern System,' Security Studies 21/1 (2012), 83-111.

Gray, Colin S., 'Nuclear Weapons and the Revolution in Military Affairs,' in T.V. Paul, Richard J. Harknett, and James J. Wirtz (eds), The Absolute Weapon Revisited: Nuclear Arms and the Emerging International Order (Ann Arbor: Univ. of Michigan Press 1998).

Gupta, Shekhar, 'No First-Use Options,' Indian Express, 17 Jan. 2009.

Harknett, Richard, 'The Logic of Conventional Deterrence and the End of the Cold War,' Security Studies 4/1 (Autumn 1994), 88-9.

Holmes, James et al., Indian Naval Strategy in the Twenty-First Century (London: Routledge 2009).

Hundley, Tom, 'Pakistan and India: Race to the End,' Foreign Policy, 5 Sept. 2012, <www. foreignpolicy.com/articles/2012/09/05/race_to_the_end>.

Huth, Paul K., Standing Your Ground (Ann Arbor: Univ. of Michigan Press 1996).

Huth, Paul K. and Bruce Russett, 'What Makes Deterrence Work? Cases from 1900 to 1980,' World Politics 36/4 (July 1984), 496-526.

'India Accuses Pakistan of Maintaining 'Militant Camps' Along Border,'The Express Tribune (Pakistan), 4 Dec. 2012.

India and Pakistan, 'Agreement on Advance Notice on Military Exercises, Maneuvers and Troop Movements,' 6 April 1991, UNTS No. 31420, <http://reaties.un.org/doc/publication/unts/ volumeper cent201843/volume-1843-i-31420-english.pdf>.

'Indian Army and Air Force Conduct Joint Exercise in Rajasthan,' DefenceNow, 11 May 2011.

'Indian Army Summer Battle Exercise in Rajasthan,' DefenceNow, 28 April 2012.

International Institute for Strategic Studies, The Military Balance 1992 (London: OUP for IISS 1992).

International Institute for Strategic Studies, The Military Balance 1997 (London: OUP for IISS 1997).

International Institute for Strategic Studies, The Military Balance 2002 (London: OUP for IISS 2002).

International Institute for Strategic Studies, The Military Balance 2007 (London: OUP for IISS 2007).

International Institute for Strategic Studies, The Military Balance 2012 (London: Routledge for IISS).

International Institute for Strategic Studies, The Military Balance 2015 (London: Routledge for IISS 2015).

Iqbal, Anwar, 'Pakistan's Response to Attack Will Be Intense, Says Report,' Dawn, 21 Jan. 2010. Jaspal, Zafar Nawaz, 'Perilous Indian Military Buildup,'Weekly Pulse, 2 Nov. 2012.

'Jordanian F-16 Jets to Enhance Capability of PAF,' Pakistan Tribune, 21 May 2014. 
Jones, Rodney W., Conventional Military Imbalance and Strategic Stability in South Asia (Univ. of Bradford: South Asian Strategic Stability Unit March 2005).

Joseph, Josy, 'Army's Demand for Attack Choppers Triggers Fresh Turf War with IAF,' Times of India, 14 July 2012.

Joshi, Shashank, 'Pakistan's Tactical Nuclear: Nightmare: Deja' Vu?', Washington Quarterly 36/3 (Summer 2013), 159-72.

Kanwal, Gurmeet, Indian Army Modernization Needs a Major Push (New Delhi: India Strategic, Feb. 2010).

Kanwal, Gurmeet, 'Military Dimensions of the 2002 India-Pakistan Standoff - Planning and Preparations for Land Operations,' in Zachary S. Davis (ed.), The India-Pakistan Military Standoff: Crisis and Escalation in South Asia (New York: Palgrave MacMillan 2011), 67-95.

Kanwal, Gurmeet, India's Military Modernization: Plans and Strategic Underpinnings (Washington DC: National Bureau of Asian Research, Sept. 2012).

Kapur, Vivek, Transformation of the Indian Air Force over the Next Decade (New Delhi: Institute for Defence Studies \& Analysis, 13 June 2012).

Kerr, Paul K., and Mary Beth Nikitin, Pakistan's Nuclear Weapons: Proliferation and Security Issues (Washington DC: Congressional Research Service, 10 May 2012).

Khan, Feroz, 'Minimum Deterrence: Pakistan's Dilemma,' RUSI Journal 156/5 (Oct. 2011), 44-51.

Khan, Khurshid, Limited War under the Nuclear Umbrella and Its Implications for South Asia (Washington DC: Henry L. Stimson Center May 2005).

Khan, Zulfqar, India-Pakistan Nuclear Rivalry: Perceptions, Misperceptions, and Mutual Deterrence (Islamabad: Islamabad Policy Research Institute, Jan. 2005).

Koblentz, Gregory, Strategic Stability in the Second Nuclear Age (Washington DC: Council on Foreign Relations 2014).

Krepon, Michael, 'Tac Nukes in South Asia,' Arms Control Wonk, 18 April 2012, <http://krepon. armscontrolwonk.com/archive/3419/tac-nukes-in-south-asia>.

Kulkarni, Pranav, 'Manohar Parrikar Greenlights Purchase of 814 Artillery Guns,' Indian Express, 23 Nov. 2014.

Kumar, Virander and P.K. Gautam, 'Back to the Basics: Foot and Hoof Mobility in the Mountains,' IDSA Policy Brief (14 Oct. 2011).

Ladwig III, Walter C., 'A Cold Start for Hot Wars? The Indian Army's New Limited War Doctrine,' International Security 32/3 (Winter 2007/08), 158-90.

Ladwig III, Walter C., 'Drivers of Indian Naval Expansion,' in Harsh V. Pant (ed.), The Rise of the Indian Navy: Internal Vulnerabilities, External Challenges (Farnham, UK: Ashgate 2012), $19-40$.

Lambeth, Benjamin S., 'Airpower in India's 1999 Kargil War,' Journal of Strategic Studies 35/3 (June 2012), 289-316.

Lavoy, Peter R., 'Islamabad's Nuclear Posture: Its Premises and Implementation,' in Henry D. Sokolski (ed.), Pakistan's Nuclear Future: Worries Beyond War (Carlisle, PA: US Army War College, Jan. 2008), 129-65.

Levy, Jack S., 'Quantitative Studies of Deterrence Success and Failure,' in Paul C. Stern et al. (eds), Perspectives on Deterrence (New York: OUP 1989), 98-133.

Levy, Jack S., 'Prospect Theory and International Relations: Theoretical Applications and Analytical Problems,' Political Psychology 13/2 (June 1992), 279-312.

Lodhi, Maleeha, 'Pakistan's Nuclear Compulsions,' The News, 6 Nov. 2012.

Machiavelli, Niccolo, The Prince [1513] (Oxford: OUP 1984).

Malvesti, Michele L., 'Bombing Bin Laden: Assessing the Effectiveness of Air Strikes as a CounterTerrorism Strategy,' The Fletcher Forum of World Affairs 26/1 (Winter 2002), 17-29.

Markey, Daniel, 'Terrorism and Indo-Pakistani Escalation,' Contingency Planning Memorandum No. 6 (Washington DC: Council on Foreign Relations Jan. 2010). 
Mearsheimer, John J., Conventional Deterrence (Ithaca, NY: Cornell UP 1983).

Mearsheimer, John J., 'Assessing the Conventional Balance: The 3:1 Rule and Its Critics,' International Security 13/4 (Spring 1989), 54-89.

Mearsheimer, John J., The Tragedy of Great Power Politics (New York: W.W. Norton 2001).

Mirski, Sean, 'Stranglehold: The Context, Conduct and Consequences of an American Naval Blockade of China,' Journal of Strategic Studies 36/3 (June 2013), 385-421.

Mustafa, Malik Qasim, 'Pakistan's Military Security and Conventional Balance of Power,' Strategic Studies 29/1 (Spring 2009), 35-44.

Narang, Vipin, 'Posturing for Peace? Pakistan's Nuclear Postures and South Asian Stability,' International Security 34/3 (Winter 2009/10), 38-78.

Nayak, Polly and Michael Krepon, The Unfinished Crisis: US Crisis Management after the 2008 Mumbai Attacks (Washington DC: Henry L. Stimson Center 2012).

'Need a Fix', Defense Industry Daily, 21 March 2013, <www.defenseindustrydaily.com/swedenfinalizes-saab-2000-aewc-contract-with-pakistan-02377>.

Newton-Small, Jay, 'Next Stop, Sacramento?' Time, 23 April 2009.

'No-Win Situation Vital to Peace Says Musharraf,' The News, 12 Aug. 2003.

'Only Ten Days of Ammunition Left?' Zeenews Bureau, 6 April 2012.

Organiski, A.F.K., World Politics (New York: Knopf 1968).

Oswald, Rachel, 'Pakistan-India Arms Race Destabilizing Strategic Balance, Experts Say,' Global Security News Wire, 20 July 2011.

Owens, William A., Lifting the Fog of War (Baltimore, MD: Johns Hopkins UP 2001).

'Pakistan Army: Modernization, Arms Procurement and Capacity Building,' Centre for Land Warfare Studies, New Delhi, India, 21 Feb. 2011.

'Pakistan Has Quality Army, India Has Quantity, Say Experts,' Agence France-Presse, 22 May 2002.

'Pak's Conventional Deterrence Averted War: Musharraf,' Rediff, 22 June 2002.

'Pakistan Imports Crude Oil Worth \$15 billion,' The News, 30 Jan. 2014.

Pandit, Rajat, 'MMRCA Deal: Rafael Negotiations Expected to be Wrapped Up in 3 Months,' Times of India, 3 June 2014.

Pandit, Rajat, 'Army's Ammunition Won't Last 20 Days of War,' Times of India, 25 Aug. 2014.

Pandit, Rajat, 'Amid Sniping by Rivals, France Aims to Close Rafael Deal by Early 2015,' Times of India, 30 Oct. 2014.

Pant, Harsh V., 'India in Afghanistan: A Rising Power or a Hesitant Power?' (paper presented at the CIPSS Speaker Series on International Security and Economy, McGill Univ., 5 April 2012).

Pape, Robert, Bombing to Win: Air Power and Coercion in War (Ithaca, NY: Cornell UP 1996).

'Parakram Killed More Than Kargil,' Times of India, 2 Aug. 2003.

Pardesi, Manjeet S., The Impact of RMA on Conventional Deterrence: A Theoretical Analysis (Singapore: Institute of Defense and Strategic Studies Dec. 2005).

Patel, Y. I., 'Dig Vijay to Divya Astra—a Paradigm Shift in the Indian Army's Doctrine,' Bharat Rakshak Monitor 6/6 (May/June 2004).

Pawar, Lt. Gen. B.S., 'Indian Army Aviation Corps: Today and Tomorrow,' Defence and Security Alert, Oct. 2012.

Peters, John E. et al., War and Escalation in South Asia (Santa Monica, CA: RAND Corporation 2006).

Raman, B., 'Make Them Pay,' Outlook, 23 Feb. 2010.

Ramana, M. V. and Zia Mian, 'The Nuclear Confrontation in South Asia,' in SIPRI Yearbook 2003 (Oxford: OUP 2003). 195-212.

Rehman, Iskander, 'The Indian Navy Has a Big Problem: The Subsurface Dilemma,' The National Interest, 4 Nov. 2014, <http://nationalinterest.org/feature/the-indian-navy-has-big-problem-thesubsurface-dilemma-11598>. 
Richter, Paul, 'US Study of War on Yugoslavia Aimed at Boosting Performance,' Los Angeles Times, 10 July 1999.

Sagan, Scott D., 'Why Do States Build Nuclear Weapons? Three Models in Search of a Bomb,' International Security 21/3 (Winter 1996-1997), 54-86.

Sahgal, Arun, and Vinod Anand, 'Revolution in Military Affairs and Jointness,' Journal of Defence Studies 1/1 (Aug. 2007), 114.

Samanta, Pranab Dhal, 'New Pak Doctrine: Deploy at Border If Terror Strike in India,' Indian Express, 8 Jan. 2012.

Schmitt, Gary and Sadanand Dhume, 'Can India's Military Be Fixed?' Weekly Standard 19/40 (June 2014).

Shafer, D. Michael, 'The Unlearned Lessons of Counterinsurgency,' Political Science Quarterly 103/1 (Spring 1988), 57-80.

Sharma, Kartikeya, and Gautam Datt, 'Parliamentary Standing Committee on Defence Admits Shortage of Ammunition,' India Today, 23 April 2012.

Sheehan, Michael, 'The Changing Character of War,' in John Baylis, Steve Smith, and Patricia Owens (eds), The Globalization of World Politics (New York: OUP 2007).

Shukla, Ajai, 'First Tejas Rolls Out,' Business Standard, 3 Oct. 2014.

Singh, Pushpindar, Himalayan Eagles: History of the Indian Air Force (New Delhi: The Society for Aerospace Studies 2007).

Sood, V.K. and Pravin Sawhney, Operation Parakram: The War Unfinished (Thousand Oaks, CA: Sage Publications 2003).

Srivastava, Siddharth, 'Indian Army “Backed Out” Of Pakistan Attack,' Asia Times, 21 Jan. 2009. Srivastava, Siddharth, 'Indian Arms Spree on the Fast Track,' Asia Times, 4 June 2009.

Stam, Allan C., Win, Lose or Draw (Ann Arbor: Univ. of Michigan Press 1996).

'Structural Problems and Lack of Transparency Continue to Plague India's Arms Procurement Policy,' DNA India, 3 Jan. 2014.

Stone, John, 'Conventional Deterrence and the Challenge of Credibility,' Contemporary Security Policy 33/1 (April 2012), 108-23.

Syed, Baqir Sajjad, 'Minimum N-Deterrence Will Be Maintained: FO,' Dawn, 21 May 2009.

Tarapore, Arzan, 'Holocaust or Hollow Victory: Limited War in Nuclear South Asia,' IPCS Research Papers, No. 6 (New Delhi: Institute of Peace and Conflict Studies, Feb. 2005).

Tellis, Ashley J., Stability in South Asia (Santa Monica, CA: RAND 1997).

Tellis, Ashley J. et al., Measuring National Power in the Postindustrial Age (Santa Monica, CA: RAND 2000).

Thayer, Bradley A., 'The Political Effects of Information Warfare: Why New Military Capabilities Cause Old Political Dangers,' Security Studies 10/1 (Autumn 2000), 43-85.

The Air War over Serbia: Aerospace Power in Operation Allied Force (Washington DC: United States Air Force 1 April 2000).

Thomas, Raju, 'The South Asian Security Balance in a Western Dominant World,' in T.V. Paul, James J. Wirtz, and Michel Fortmann (eds) Balance of Power: Theory and Practice in the 21st Century (Stanford UP 2004).

Tzu, Sun, The Art of War, trans. Lionel Giles (El Paso, TX: Norte Press 2009).

Unnithan, Sandeep, 'Not Ready for War,' India Today, 29 Oct. 2011.

'War in a Wind Blown Waste,' Life, 11 June 1965.

Watts, Barry D., The Maturing Revolution in Military Affairs (Washington DC: Center for Strategic and Budgetary Assessments 2011).

Weitz, Richard, 'South Asia’s Nuclear Arms Racing,' The Diplomat, 1 Oct. 2011.

Wirtz, James J. and Surinder Rana, 'Surprise at the Top of the World: India's Systemic and Intelligence Failure,' in Lavoy, Asymmetric Warfare in South Asia, 207-30.

Wylie, Joseph, Military Strategy: A General Theory of Power Control (Annapolis, MD: Naval Institute Press 2014) 